\title{
Las Cortes y el gobierno de la oligarquía, 1430-1432: los fundamentos de un nuevo soporte institucional *
}

\author{
The Cortes and the government of the oligarchy, 1430-1432: \\ the underpinnings of a new institutional framework
}

\author{
Vicente Ángel Álvarez Palenzuela **
}

\begin{abstract}
RESUMEN
Finalizada la guerra con Aragón y Navarra se forma en Castilla un grupo oligárquico que controlará el poder en Castilla en los

próximos años. Las Cortes plantean numerosas peticiones para hacer frente a los daños y resolver los graves problemas causados por la guerra; sus consecuencias y los proyectos del equipo gobernante obligan a las ciudades a hacer frente a una pesada carga fiscal. En esas circunstancias los procuradores tratan de defender los intereses de sus ciudades, corregir abusos y corrupciones

$y$, sobre todo, recomponer el reino, recuperar el orden y construir los fundamentos de un verdadero soporte institucional.
\end{abstract}

\section{PALABRAS CLAVE}

Juan Il de Castilla. Álvaro de Luna. Cortes de Castilla. Fiscalidad. Oligarquía castellana. Infantes de Aragón.

\begin{abstract}
Once the war with Aragon and Navarre had concluded, an oligarchic group was created to control Castilian politics for the following years. The Cortes (the Castilian parliament) issued several petitions to settle damages and resolve serious problems caused by the war. The ensuing consequences of the conflict and the new project of the governing clique forced a heavy tax burden onto the cities. Under these circumstances, parliamentary representatives attempted to defend the interests of the cities, correct abuses and corruption and, above all, rebuild the kingdom, impose order and establish the foundations for an authentic institutional framework.
\end{abstract}

\section{KEY WORDS}

Juan II de Castilla, Álvaro de Luna, Cortes (Castilian parliament), taxation, Castilian oligarchy, Infantes of Aragón.

\footnotetext{
* Fecha de recepción del artículo: 2013-1-19. Fecha de aceptación del artículo: 2013-2-1.

Este trabajo forma parte del Proyecto de Investigación «El ejercicio del poder en el reino de Castilla en la primera mitad del siglo XV», referencia HAR2009-09912, financiado por la DGICYT.

** Universidad Autónoma de Madrid. C.e.: vicente.alvarezp@telefonica.net
} 
La firma de las treguas de Majano supone un severo revés para los proyectos de los Infantes de Aragón ${ }^{1}$. El documento firmado ni siquiera plantea la posibilidad de devolución del patrimonio que les había sido confiscado; en su artículo segundo se otorga a los Infantes y a sus seguidores, aunque fuesen castellanos, seguridad personal y de los bienes que poseían en ese momento, aún así con prohibición absoluta de entrar en Castilla durante los cinco años de duración de las treguas. También se estipula, artículo XI, el nombramiento, en el plazo de treinta días de la firma de las treguas, de una comisión de catorce miembros, que residirían en Tarazona y Ágreda, dotados de amplios poderes para resolver las dudas de interpretación de los acuerdos, y para poner fin a todas las disensiones y debates que surjan, pero cuya causa sea solamente la presente guerra, no hechos anteriores.

De hecho se daba prácticamente por seguro, como así fue, que los infantes Enrique, Catalina y Pedro no aceptarían las treguas: en ese supuesto el artículo dieciocho preveía que no fueran auxiliados en forma alguna por los reyes de Aragón y de Navarra, ni recibidos en sus reinos, además de recaer sobre ellos la pena de confiscación de bienes prevista en el artículo séptimo para quienes quebranten las treguas.

Aunque se trataba solamente de unas treguas, se pretendía cerrar el pasado. Alfonso V podía afirmar que había cumplido su papel de defensor de los intereses familiares en Castilla y obtenía una salida airosa de una guerra a la que le habían forzado las provocaciones castellanas y en la que no había querido implicarse a fondo porque la consideraba un obstáculo a sus verdaderos proyectos²; el infante don Juan, que contaba al menos con Navarra, podía esperar nuevas oportunidades. Además, se daba satisfacción a Juan I de Portugal que no deseaba alteraciones en la situación peninsular, ahora que la paz entre Portugal y Castilla parecía encauzada. Cierto que los infantes Enrique y Pedro, que perdían todo con este re-

1 Fueron estudiadas por M. GUAL CAMARENA, «Las treguas de Majano entre Aragón, Navarra y Castilla (1430), Cuadernos de Historia de España, 16, 1951, 79-109, utilizando la copia procedente del Archivo Municipal de Valencia, Manuals de Consells, 29a ${ }^{2} 2^{a}$ parte, f. 22r-36r. Otro ejemplar en A.G.S. Secretaría de Estado, leg. 1482.

2 Alfonso $\mathrm{V}$ intentó resolver los problemas familiares en Castilla del modo más sencillo: negociación diplomática, mediación de su esposa María o contactos con nobles castellanos adictos; cuando se hace precisa una intervención armada, se plantea ésta de modo limitado, aunque con gran alarde publicitario, y con garantías de que será posible eludir el choque abierto y disponer de una retirada airosa. La reina María y el cardenal de Foix, al que utiliza con el señuelo de un final acordado del Cisma, son ese seguro. Así lo puse de relieve en mi obra Extinción del Cisma de Occidente. La legación del Cardenal Pedro de Foix en Aragón. 1425-1430. Madrid, Universidad Autónoma, 1977, y en «Relaciones entre Aragón y Castilla en época de Alfonso V. Estado de la cuestión y líneas de investigación». La Corona d’Aragona ai tempi di Alfonso Il el Magnánimo. XVI Congresso Internazionale di Storia della Corona d’Aragona. Nápoles, Paparo Edizioni, Comune di Napoli, 2000, vol. I pp. 21-43. Aún en el momento en que Alfonso $\mathrm{V}$ prepara su entrada en Castilla, el mayor volumen de sus gastos se realiza en construcción naval: su verdadero objetivo es Nápoles. Vid. MARTíNEZ SANMARTIIN, L.P. «Guerra, estado y organización social de la producción: la Corona de Aragón en guerra con Castilla. 1429-1430». Anuario de Estudios Medievales, 23, 1993, 445-471. 
sultado, prorrogaban su resistencia en Extremadura, pero, sin el respaldo de sus hermanos y el apoyo portugués, no cabía augurar posibilidad alguna a su iniciativa.

De hecho, la firma de las treguas supone el comienzo del gobierno de un grupo oligárquico, reforzado con las posesiones confiscadas a los Infantes en febrero de 1430, presidido por don Álvaro, que, mediante su segundo matrimonio, entroncaba con los miembros más poderosos de esa oligarquía; no puede hablarse de un gobierno personal del Condestable porque, y ahí reside su debilidad, los objetivos de unos y otros son muy diferentes: éste trata de reforzar el poder monárquico, que entiende como el suyo propio; aquéllos pretenden el engrandecimiento de los respectivos linajes.

\section{LOS MALES DE UNA GUERRA LIMITADA.}

Guerra limitada, pero cara; a los cuantiosos gastos provocados por la movilización de tropas hay que sumar los daños causados por la campaña en tierras de la Orden de Santiago y en Extremadura, y especialmente las destrucciones en la frontera común: Monreal, Cetina y Ariza, tomadas por los castellanos; Deza, Vozmediano, Ciria y Borovia, destruidas por los aragoneses. Juan II se ve obligado a tomar medidas muy dañinas: acuñación de moneda de mala calidad, préstamos forzosos y requisa de plata de las iglesias; de ello se quejarán las Cortes y demandarán soluciones.

También se ha hecho necesario reclamar de las Cortes un esfuerzo contributivo: en Illescas, en enero de $1429^{3}$, los procuradores habían otorgado cuarenta y cinco millones, en quince monedas y pedido y medio, así como diversas cantidades pendientes de cobro que podrían ascender a unos treinta millones más, para la guerra de Granada 4 : lo cierto es que las treguas vigentes fueron prorrogadas y estos fondos se emplearon en la guerra con Aragón. A primeros de diciembre de este año, en Medina del Campo, los procuradores otorgan un nuevo subsidio de otros cuarenta y cinco millones ${ }^{5}$. De regreso en Medina del Campo, a finales de enero de 1430, tras la expedición por Extremadura, convoca nuevamente el rey a

\footnotetext{
${ }^{3}$ La Corte reside en esta villa los meses de enero a marzo de 1429. Vid. F. de P. CAÑAS GÁLVEZ, EI itinerario de la Corte de Juan II de Castilla (1418-1454). Madrid, Sílex, 2007. (Itinerario), pág. 241.

${ }^{4}$ Carecemos de Cuadernos de estas Cortes. Solo disponemos de la noticias proporcionadas por $\mathrm{F}$. PÉREZ DE GUZMÁN, Crónica de Juan II, Edición de Cayetano Rosell. Biblioteca de Autores Españoles, tomo 68. Madrid 1947. (Crónica). También A. GARCIA DE SANTA MARÍA, Crónica de don Juan I/ de Castilla. Colección de documentos inéditos para la Historia de España. Tomo 100. Madrid 1891, p. 40. (CODOIN, 100). Convocadas en Segovia en septiembre u octubre de 1428, Itinerario, pág. 237, para, teóricamente, deliberar sobre la prórroga larga demandada por los moros, Crónica, 1428, c. XIV, p. 449, se reunieron en Illescas. El monarca designó a Pedro Manrique, y a los doctores Pedro Yáñez y Diego Rodríguez para negociar con los procuradores el subsidio que otorgarían para la guerra con Granada que, junto con los contadores fue estimado en la cantidad indicada. Crónica, 1429, c. III, p. 451.

5 El rey llega a Medina del Campo el 5 de diciembre. Itinerario, p. 248; pocos días después lo hacen los procuradores a quienes el rey expone las necesidades provocadas por la guerra. Negocian el subsidio los mismo delegados regios que lo hicieron en Illescas. Crónica, 1429, c. XLIII, p. 471-472.
} 
las Cortes, que se reunirán en Burgos, en mayo de 1430, a punto de comenzar una nueva campaña en la guerra contra Aragón y Navarra, aunque ahora no habrá nuevos combates sino treguas: otorgan un nuevo subsidio de treinta millones, pero se niegan a pronunciarse sobre las medidas a adoptar contra los Infantes, sin previa consulta a sus respectivas ciudades ${ }^{6}$.

No es apacible el ambiente en que se reúnen las Cortes en la primavera burgalesa de 1430, y no creo que pueda hablarse de docilidad de la institución a las demandas regias. El cuaderno de estas Cortes ${ }^{7}$, fechado en Burgos el 20 de mayo, trasmite una gran tensión, visible no solamente en el contenido de las peticiones sino también en el hecho, nada anecdótico, de que veintiséis de las cuarenta respuestas regias fueran replicadas por las Cortes; las respuestas del monarca son, en general, positivas, algunas lo son «si es posible» y otras se escudan en la evasiva fórmula de que «mandaré verlo y proveeré como cumpla a mi servicio...». Incluso una de las peticiones, la decimosexta, recibe, como veremos, una seca respuesta a la réplica de los procuradores.

El contenido de las peticiones gira en torno a la precaria situación del reino, las dificultades económicas del estamento ciudadano, especialmente derivadas de la asfixiante presión fiscal, la necesidad de adoptar medidas de saneamiento económico, reordenación administrativa y recuperación del orden, y, como es lógico, la defensa de los intereses y de los privilegios de las ciudades.

Las Cortes expresan, en primer lugar, su deseo de que se haga la paz con Aragón y Navarra, y con todos los reinos cristianos vecinos, es decir, Portugal, aunque no se le menciona; reclaman que, si ha de proseguir la guerra, las tropas convocadas se reúnan en el lugar y tiempo ordenado, y en el número convocado, que se eviten los habituales fraudes y se castiguen con dureza los que se produz$\mathrm{can}^{8}$. A la esperable respuesta regia de que así le placía ordenarlo, replican los procuradores que era conveniente que les informase acerca del curso de la guerra, como hicieron los monarcas anteriores, y sobre los fraudes en el número de tropas, y que diese orden escrita para su cumplimiento, con fuerza de ley.

En esta misma línea, se reclaman castigos para quien participe en más de un alarde, para cuyo control se pide que solo se haga con caballero o señor, y, en la réplica a la respuesta regia, se solicita una disposición con rango de ley, a lo que

6 Crónica, 1430, c. III, p. 479. Aunque las Cortes votan elevados subsidios con aparente facilidad, ascienden a ciento cincuenta millones las cantidades votadas en poco más de un año, muestran una clara resistencia a intervenir como meros comparsas en las luchas internas del reino.

7 Fue publicado en Cortes de los antiguos reinos de León y Castilla. Real Academia de la Historia. Madrid 1886, (Cortes), tomo III, f. 70-97; tomado de Archivo Municipal de Madrid. La Biblioteca Nacional de España, Sección Manuscritos, custodia los siguientes con el texto completo de este cuaderno: 1220, f. 70r-92; 10649, f. 297r-327v; 11128, f. 105r-143v; 13105, f. 1r-22v, y 13259, f.54v-61r. Otros manuscritos contienen solo alguna de las peticiones; son los siguientes: 1019, f. 20v-22v; 6720, f. 30r-32v; 11533, f. 504r-524r; y 13104, f. 197r-202v.

8 Petición primera. Cortes, III, f. 80; B.N.E. MSS/1220, f. 70r-71v;10649, f. 298r-299v; 11128, f. $106 v-108 v ; 11533$, f. 509r-509v; 13105, f. 2v-3v, y 13259, f. 54r-54v. 
accede el monarca disponiendo penas severas ${ }^{9}$. Se pide también que los hombres de armas sean adecuadamente pagados, lo que pretende mayor eficacia de las tropas, disminución del fraude y supresión del peligro que suponen combatientes insatisfechos y mal pagados ${ }^{10}$.

Los procuradores solicitan que excuse a las ciudades de las levas de avituallamientos y pertrechos, en la forma en que hasta ahora se han hecho, y denuncian que resultan más gravosas y dañinas que los importantes servicios votados en los últimos meses ${ }^{11}$. La respuesta regia, prometiendo que así se hará en cuanto sea posible, causa otra petición ${ }^{12}$, reclamando que, cuando tales levas sean inevitables, se hagan con el menor coste y daño posible, y que se replique a la vaga respuesta regia que es preciso considerar los males causados por estas levas, realizadas sin una ordenanza que regule el procedimiento, y con un importe económico que los procuradores estiman superior al triple de las cantidades recaudadas en concepto de pedido y monedas.

Dado que no es posible soportar estos ruinosos gravámenes, reclaman que se dicte una normativa que regule razonablemente esta carga porque, de no hacerlo, no se cumple ni con aquello que sería posible asumir y en lo que se cumple se hace con grandes dilaciones. El monarca delega en el adelantado Pedro Manrique y en los Contadores para que informen en detalle a las Cortes de las medidas adoptadas.

Desde luego se hace imprescindible castigar los fraudes cometidos e impedir que se produzcan en el futuro, como se contiene en la sexta petición ${ }^{13}$. La réplica a la protocolaria respuesta regia, mandar hacerlo como se le pide, demanda adecuadas disposiciones legales, con las penas pertinentes, y obtiene la efectiva constitución de una comisión integrada por Pedro Manrique, los doctores Pedro Yáñez y Diego Rodríguez, todos ellos miembros del Consejo, junto con dos procuradores designados por los propios representantes de las ciudades, y el compromiso de hacer pública y con vigor de ley la ordenanza por ellos redactada. Relacionados con los desafueros en la realización de levas están las exigencias de

9 Petición segunda. Cortes, III, f. 80-81; B.N.E. MSS/1220, f. 71v; 6720, f. 30r; 10649, f. 299v-300r; 11128, f. 108v-109r; 11533, f. 510r; 13104, f. 198r; 13105, f. 3v-4r, y 13259, f. 54v. Se establece una pena de diez años de servicio en las atarazanas, si el defraudador es hidalgo, y cien azotes para los hombres de menor condición.

10 Petición tercera. Cortes, III, f. 81; B.N.E. MSS/1220, f. 71v-72r; 10649, f. 300r; 11128, f. 109r-109v; 11533, f. 510r; 13105, f. 4r, y 13259, f. 54v.

11 Petición cuarta. Cortes, III, f. 81. B.N.E. MSS/1220, f. 72r-72v; 10649, f. 300r-300v; 11128, f. $109 v-110 r ; 11533$, f. 510r-510v; 13105, f. 4r-4v, y 13259, f. 54v.

12 Petición quinta. Cortes, III, f. 81-82; B.N.E. MSS/1220, f. 72v-73r; 10649, f. 300v-302r; 11128, f. $110 \mathrm{r}-111 \mathrm{v} ; 11533$, f. 510v-511r; 13105 , f. 4v-5r, y 13259, f. 54v-55r.

13 Cortes, III, f. 82-83; B.N.E. MSS/1220, f. 73v-74v; 10649, f. 302r-303r; 11128, f. 111v-113r; 11533, f. 511r-512r; 13105, f. 5r-6r, y 13259, f. 55r-55v. Los fraudes denunciados son: expedición de albaláes de recibo por viandas y pertrechos no recibidos; exacciones excesivas por quienes las hacían, o ilícitas por quienes ni siquiera debían hacerlas; y cobro de aranceles abusivos por la expedición de albaláes. Todo ello suponía un abastecimiento engañoso de las tropas, con los consiguientes peligros, y la realización de un gran esfuerzo por parte de las ciudades, además estéril en gran parte. 
algunos capitanes de frontera que requieren el transporte de aprovisionamientos a grandes distancias, lo que aconseja la asignación de determinadas zonas a cada capitán para evitar, además, demandas múltiples sobre una misma comarca ${ }^{14}$.

Preocupan a los procuradores los trastornos producidos por la guerra. La llamada a filas de los labradores, que, además de convocar efectivos poco eficaces, desarticula la producción y les somete a obligaciones que, unidas a las económicas que ya soportan, darán lugar a la despoblación de algunos lugares; la protocolaria respuesta regia motiva una réplica pidiendo que se legisle al respecto y una nueva respuesta nada convincente: se ha hecho lo mejor posible ${ }^{15}$. También, la toma de objetos de iglesias y monasterios, especialmente los dedicados al culto, en los que, según se deduce, se han incluido crucifijos e imágenes de la Virgen. La afirmación regia de que no se han producido tomas, sino préstamos, motiva una severa queja por la forma en que se han hecho las tomas, tal que no permite admitir que se trate de préstamos. Piden que se trate este problema, que no se repita una actuación de este tipo y afirman que, en todo caso, la decisión debería haberse discutido previamente ${ }^{16}$.

Es evidente que este asunto ha causado profunda irritación porque dos nuevas peticiones insisten en él: la que reclama que las tomas que hayan de hacerse se ajusten a derecho, a lo que se responde negando nuevamente que se haya tratado de tomas, sino de acciones previstas en la ley ${ }^{17}$, y la que pide que los préstamos se pidan adecuadamente, sin violencias. La respuesta a esta última es una aceptación indirecta de que se han producido excesos, aunque no ordenados por el rey; a pesar de ello se reclama provisión regia al respecto, a la que el rey accede ${ }^{18}$.

Esta situación requiere la adopción de medidas de gobierno, en particular, las relativas a la administración de justicia. Se pide un eficaz funcionamiento de la Audiencia, que evite innecesarios gastos a las partes, a cuyo efecto entienden es preciso que esté permanentemente un prelado a su frente, y que se guarde el turno de los oidores. Aunque se ha designado presidente a don Gutierre Gómez de Toledo, obispo de Palencia, su prolongada ausencia, por razones de gobierno, hace que las Cortes pidan el nombramiento de un sustituto que, durante la ausencia de aquél, asuma sus funciones. Diego Gómez de Fuensalida, obispo de Ávila,

14 Petición trigésimo primera. Cortes, III, f. 92-93; B.N.E. MSS/1220, f. 86v;6720, f. 31; 10649 , f. 319v-320r; 11128, f. 132v-133v; 11533, f. 521; 13104, f. 200r-200v; 13105, f. 17v, y 13259, f. 59 v.

15 Petición séptima. Cortes, III, f. 83. B.N.E. MSS/1220, f. 74v-75r; 10649, f. 303v-304r; 11128, f. $113 v-114 v ; 11533$, f. 512r; 13105, f. 6r-6v, y 13259, f. 55v.

${ }^{16}$ Creo que el tono, la insistencia y la exigencia de una previa discusión del asunto no permite hablar de una actitud sumisa de las Cortes; es cierto que sus peticiones, como veremos, se repiten en numerosas ocasiones, lo que demuestra su escaso cumplimiento, pero, a mi juicio, eso no hace menos firme la actitud de las Cortes. Petición octava. Cortes, III, f. 83-84. B.N.E. MSS/1220, f. 75r-76r; 10649, f. 304r-305v; 11128, f. 114v-116r; 11533, f. 512r-513r; 13105, f. 6v-7r, y 13259, f. 55v-56r.

17 Petición novena. Cortes, III, f. 84. B.N.E. MSS/1220, f. 76r; 10649, f. 305v; 11128, f. 116r; 11533, f. $513 r ; 13105$, f. $7 \mathrm{v}$, y 13259 , f. 56 r.

18 Petición décima. Cortes, III, f. 84. B.N.E. MSS/1220, f. 76r-76v; 10649, f. 305v-306r; 11128, f. $116 v-117 r ; 11533$, f. 513r-513v; 13105, f. 7v-8r, y 13259, f. 56r. 
será el prelado designado al efecto ${ }^{19}$. En cuanto al turno de oidores promete el rey proveer como cumpla a su servicio, pero la exigencia de las Cortes de que se respete la costumbre obliga a un compromiso en ese sentido ${ }^{20}$.

Los desórdenes producidos por la guerra dan ocasión a excesos de los poderosos: detenciones arbitrarias, cárceles privadas y manejo del orden público por los particulares; por ello las Cortes piden que las órdenes de detención emanen únicamente de los jueces, que las ejecuten alguaciles y merinos, que la prisión se cumpla únicamente en cárceles públicas y que no haya carceleros nombrados por personas privadas. Lo admite el rey, pero, tratándose de un cómodo instrumento también utilizado por él, lo hace a reserva de sus propias disposiciones en contrario, lo que motiva una réplica pidiendo que se regule por norma ${ }^{21}$.

Especial incidencia tienen los excesos cometidos por los jueces eclesiásticos que emplazan a los laicos directamente ante los jueces mayores de los obispados, con los consiguientes gastos, amparan los excesos de los arrendadores de los diezmos, dictan prisiones y ejecución de bienes por sí mismos, y responden con excomuniones a las pretensiones de los oficiales regios de defender su jurisdicción. Es un mal muy extendido, que afecta al arzobispado de Toledo, a los obispados de Cuenca y Jaén y, en general, a todas las ciudades episcopales ${ }^{22}$, y para cuya extirpación no han bastado las cartas reales, por lo que se piden advertencias firmes a todos los eclesiásticos sobre las penas en que incurrirán por no respetar la jurisdicción real ${ }^{23}$.

Junto a los problemas generales del reino que afectan a las ciudades, preocupación habitual de las Cortes, la defensa de sus intereses y privilegios constituye, más aún en la situación del momento, un objetivo preferente al que se dedican casi la mitad de las peticiones del cuaderno. Su primera preocupación es mantenerse dentro del realengo, evitando su cesión a señorío, contraria a sus privilegios; la limitada respuesta regia, place en cuanto sea posible, suscita la réplica de los

\footnotetext{
19 Petición undécima. Cortes, III, f. 84-85. B.N.E. MSS/1220, f. 76v-77r; 10649, f. 306r-307v; 11128, f. $117 \mathrm{r}-117 \mathrm{v}$; 11533, f. 513v-514r, 13105, f. 8r-8v, y 13259, f. 56r-56v.

20 Petición duodécima. Cortes, III, f. 85. B.N.E. MSS/1220, f. 77r-77v; 10649, f. 307r-307v; 11128, f. 117v-118r; 11533, f. 514r; 13105, f. 8v-9r, y 13259, f. 56v.

${ }^{21}$ Petición decimoséptima. Cortes, III, f. 86-87. B.N.E. MSS/1019, f. 20v-21r; 1220, f. 79r-79v; 6720, f. 30v-31r; 10649, 309v-310v; 11128, f. 120v-121v; 11533, f. 515v-516r; 13104, f. 199r-199v; 13105, f. 10v-11r, y 13259, f. 57r.

22 Petición trigésimo octava. Cortes, III, f. 95-96. B.N.E. MSS/1019, f. 22r-22v; 1220, f. 90r-91r; 10649, f. 324v-326r; 11128, f. 139v-141r; 13104, f. 201v-202v; 13105, f. 20v-21v, y 13259, f. 61r. Los procuradores, a petición regia, señalan estos territorios como escenario de tales excesos, en realidad muy generalizados.

El concejo de Cuenca presenta una petición ante el rey protestando por este tipo de actuaciones de los jueces eclesiásticos que dificultan la recaudación de pedidos y monedas y la actuación de los cogedores. 1430, julio, 16. Cuenca. Archivo Municipal de Cuenca, leg. 187, doc. 5, f. 54r-54v. Pub. OLIVERA SERRANO, C. «Inventario de la documentación medieval de las Cortes de Castilla y León en el Archivo Municipal de Cuenca (1250-1500), En la España Medieval, 19, 347-415, doc. 92, p. 370 .

Dar cartas para los prelados sobre esta cuestión parece medida poco efectiva, como demuestra la siguiente petición.

${ }^{23}$ Petición trigésimo novena. Cortes, III, f. 96-97. B.N.E. MSS/1019, f. 22v; 1220, f. 91r-91v; 10649, f. 326r-326v; 11128, f. 141r-142r; 13105, f. 21v-22r, y 13259, f. 61r-61v.
} 
procuradores que obtiene una seca contestación, «está bien respondido»24: es que la petición, que señalaba uno de los grandes problemas de las ciudades, atacaba el fundamento mismo del crecimiento de poder de la oligarquía y del mercadeo de voluntades por el monarca.

Preocupan también las cuestiones relacionadas con el funcionamiento de las Cortes. Decisivo es el modo de designación de procuradores: se pide que sean solamente dos por ciudad, elegidos libremente por ésta, que el monarca no nombre otros distintos a los elegidos y que no sean labradores ni sesmeros. La vaga aceptación inicial motiva la réplica pidiendo disposición escrita al respecto; la respuesta, ahora más restringida, accede a que las ciudades designen libremente a sus procuradores y a fijarlo por ley ${ }^{25}$. Piden también que mande ver y provea acerca de las peticiones realizadas en estas Cortes, tanto particulares de cada ciudad como las generales, a lo que accede el monarca ${ }^{26}$, y que ordene tengan debido efecto las peticiones otorgadas en ésta y anteriores sesiones ${ }^{27}$.

Los intereses económicos de las ciudades se ven comprometidos tanto por la falta de seguridad que supone el inadecuado mantenimiento de murallas y la falta de pertrechos, especialmente en los lugares más amenazados ${ }^{28}$, como por la nula diligencia en la indemnización de los daños sufridos, aún los ya investigados ${ }^{29}$. Especialmente perjudicial resulta la concesión de nuevas ferias, exentas de alcabalas, que algunos señores otorgan a lugares de su jurisdicción, viendo el buen resultado de las de Medina del Campo. Es una muestra más del poder de la oligarquía que perjudica a las ciudades de realengo porque, al desviar las transacciones comerciales hacia las nuevas ferias exentas, hace descender el movimiento comercial en las demás y con ello provoca desabastecimiento, incremento de precios y devaluación de la renta de alcabalas ${ }^{30}$.

24 Decimosexta petición. Cortes, III, f. 86. B.N.E. MSS/1220, f. 78v-79r; 10649, f. 309r-309v; 11128, f. $120 r-120 v ; 11533$, f. 515r-515v; 13105, f. 10r-10v, y 13259, f. 57r.

${ }_{25}$ Decimotercera petición. Cortes, III, f. 85-86. B.N.E. MSS/1220, f. 77v-78r; 6720, f. 30r-30v; 10649, f. 307v-308r; 11128, f. 118r-119r; 11533, f. 514r-514v; 13104, f. 198v-199r; 13105, f. 9r-9v, y 13259, f. 56v.

${ }_{26}$ Petición vigésimo tercera. Como en otras peticiones de estas cortes, una primera respuesta favorable motiva una réplica requiriendo orden escrita y valor de ley. Cortes, III, f. 89. B.N.E. MSS/1220, f. 82r; 10469, f. 313v-314r; 11128, f. 125v-126r; 11533, f. 517v-518r; 13105, f. 13r-13v, y 13259, f. 58r.

27 Petición vigésimo cuarta. Cortes, III, f. 89. B.N.E. MSS/1220, f. 82r-82v; 10469, f. 314r; 11128, f. 126r; 11533, f. 518r; 13105, f. 13v, y 13259, f. 58r. A pesar de la petición y de la respuesta obtenida, el incumplimiento es un hecho habitual, como podremos comprobar.

28 Las ciudades requieren que ordene la reparación y adecuado abastecimiento y, no conformes con una mera promesa, piden, en réplica, que se ponga por obra. Decimocuarta petición. Cortes, III, f. 86. B.N.E. MSS/1220, f. 78r; 10649, f. 308r-308v; 11128, f. 119r-119v; 11533, f. 514v-515r; 13105, f. 9v, y 13259 , f. $56 \mathrm{v}$.

29 Por ello se pide que ordene pagar las indemnizaciones ya investigadas; tampoco es suficiente respuesta haberlo ordenado: se requiere una orden a los contadores para que lo lleven a cabo, a lo que accede el monarca. Decimoquinta petición. Cortes, III, f. 86; B.N.E. MSS/1220, f. 78r-78v; 10649, f. 308v-309r; 11128, f. 119v-120r; 11533, f. 515r; 13105, f. 9v-10r; 13259, f. 56v-57r.

30 Se demanda que ninguna feria esté libre del pago de alcabala, que los señores no puedan disponerlo y que en ningún caso gocen de exención quienes a ellas acudan. La respuesta vagamente positiva hace necesaria una réplica para que se acuerde ver este asunto de modo inmediato y resolver 
Los males producidos por la guerra no consisten solamente en un agobiante esfuerzo económico, agravado por la corrupción, los trastornos en el sistema productivo o las destrucciones directas a que da lugar, sino también las dificultades que supone para el propio gobierno de las ciudades. Los llamamientos de hidalgos han sido tan generales que, si se cumplieran, dejarían a las ciudades sin oficiales, por lo que piden que todos ellos queden exentos salvo los vasallos del rey que tienen de él tierras, raciones y quitaciones, y los cirujanos necesarios en la guerra ${ }^{31}$; además, se desarticularía el sistema de recaudación, lo que exige la exención de todos cuantos son necesarios para su funcionamiento ${ }^{32}$. Es precisa también una mayor racionalidad en la movilización, convocando solamente a los que verdaderamente sean útiles para la guerra ${ }^{33}$, y ordenando el adecuado encuadramiento de las tropas ciudadanas, con sus propios capitanes, y el oportuno pago de soldadas ${ }^{34}$. Estas medidas disminuirán el gasto e incrementarán la disciplina y la efectividad.

Preocupa a las ciudades la designación de oficiales para su gobierno, en especial la conservación de sus privilegios sobre esta materia, que últimamente no han sido respetados, una muestra más de la presión señorial y de la utilización de los cargos de la administración municipal en la lucha política. Solicitan que tales nombramientos recaigan en vecinos de la ciudad o villa en que han de desempeñar sus funciones ${ }^{35}$, que se respete la costumbre según la cual las vacantes de regimientos, escribanías y otros oficios se cubrieron a petición de los regidores y oficiales ${ }^{36}$, petición ésta en que se insiste de nuevo en otra de estas mismas cor-

con órdenes por escrito. Vigésimo quinta petición. Cortes, III, f. 89-90. B.N.E. MSS/1019, f. 21r-21v; 1220, f. 82v-83v; 10649, f. 314r-316r; 11128, f. 126r-128r; 11533, f. 518r519r; 13105, f. 13v-15r, y 13259, f. 58r-58v.

${ }^{31}$ Se pide mande excusar, salvo la excepción señalada, a todos los alcaldes, alguaciles, regidores, jurados, sesmeros, fieles, almotacenes, mayordomos, procuradores, abogados, escribanos de número, físicos, cirujanos, maestros de gramática y escribanos que enseñan lectura y escritura. Se acepta la petición solo por esta vez y, ante la réplica que solicita su aplicación durante toda esta guerra, se otorga únicamente durante el presente año. Trigésimo segunda petición. Crónica, III, f. 93-94. B.N.E. MSS/1220, f. 86v-88r; 10649, f. 320r-321v; 11128, f. 133v-135r; 11533, f. 521v-522v; 13105, f. 17v-18v, y 13259 , f. $59 \mathrm{v}-60 \mathrm{r}$.

${ }^{32}$ Es preciso excusar de convocatoria a los arrendadores, recaudadores, empadronadores, cogedores y pesquisidores de alcabalas, tercias, pedidos, monedas y otras rentas. De acuerdo con la respuesta regia ya se había dictado ordenanza relativa a arrendadores y recaudadores, pero no al resto de agentes, a los que, en virtud de la réplica, se extiende ahora dicha ordenanza, aunque únicamente por este año. Trigésimo tercera petición. Cortes, III, f. 94. B.N.E. MSS/1220, f. 88r-88v; 10649, f. 321v-322r; 11128 , f. 135 r-136v; 11533, f. 522v-523r; 13105 , f. 18v-19r, y 13259, f. 60r.

${ }^{33}$ La respuesta a esta petición asegura que se han adoptado medidas para excusar al mayor número posible. Petición trigésimo quinta. Cortes, III, f. 95. B.N.E. MSS/1220, f. 89r-89v; 10649, f. 323r-323v 11128 , f. $137 v-138$ r; 11533, f. 523v; 13105, f. 19v-20r, y 13259, f. 60v.

${ }_{34}$ Así se otorga hasta que las tropas lleguen al real; a partir de ese momento obedecerán al jefe que se les asigne. Petición trigésimo sexta. Cortes, f. 95. B.N.E. MSS/1220, f. 89v; 10649, f. 323v-324r; 11128 , f. 138r-138v; 11533, f. 523v-524r; 13105, f. 20r-20v, y 13259, f. 60v.

${ }_{35}$ Acepta el monarca, pero los procuradores replican reclamando disposición por escrito con vigor de ley, a lo que, asimismo, responde de modo positivo. Petición vigésimo octava. Cortes, III, f. 92. B.N.E. MSS/1220, f. 85r-85v; 10649, f. 318r-318v; 11128, f. 131r-131v; 11533, f. 520v; 13105, f. 16v, y 13259, f. 59r.

${ }^{36}$ Petición vigésimo novena, también aceptada. Cortes, III, f. 92. B.N.E. MSS/1019, f. 21v; 1220, f. 85v-86r; 6720, f. 31R; 10649, f. 318v; 11128, f. 131v-132r; 11533, f. 520v-521r; 13104, f. 199v; 13105 f. $16 v-17$ r, y 13259 , f. $59 r-59 v$. 
tes ${ }^{37}$, y que se supervise la actuación de corregidores y alguaciles enviados a ciudades y villas y se limite su mandato ${ }^{38}$.

No se trata solamente de poner fin a la guerra, paliar sus negativas consecuencias económicas, aliviar la presión fiscal, resolver los problemas administrativos y respetar los privilegios urbanos; es preciso que se recaude mejor lo otorgado y se gaste mejor lo recaudado. Una recaudación adecuada exige que los recaudadores no puedan arrendar a otros su recaudamiento, lo que supone pérdida de rentabilidad y es fuente numerosas corruptelas ${ }^{39}$; que la designación recaiga en personas idóneas y honestas ${ }^{40}$, que no obtengan el arrendamiento por compra o dádiva ${ }^{41}$, y que queden excluidos de estos cometidos judíos y moros, como está ordenado ${ }^{42}$.

37 En esta ocasión, petición trigésimo séptima, se hace notar que la antigua costumbre ha sido quebrantada de poco tiempo acá con el nombramiento de personas no elegidas por los regidores; se pide al monarca respeto al juramento prestado cuando tomó posesión del gobierno del reino. El rey ordena la ordenanza dispuesta sobre este asunto. Cortes, III, f. 95. B.N.E. MSS/1220, f. 89v-90r; 6720, f. 32r-32v; 10649, f. 324r-324v; 11128, f. 138r-139v; 11533, f. 524r (solo un fragmento); 13104, f. 207r-207v; 13105 , f. 20v, y 13259, f. 60v-61r.

${ }^{38}$ Las quejas se refieren a la designación por corregidores y alguaciles de oficiales sustitutos, la injustificada prolongación de su mandato, y la abusiva concentración de poder que alcanzan, lo que dificulta la posibilidad de los vecinos de querellarse contra su gestión. Se limita el mandato de estos oficiales a un máximo de dos años. Petición trigésima. Cortes, III, f. 92. B.N.E. MSS/1220, f. 86r-86v 6720, f. 31r-31v; 10649, f. 318v-319v; 11128, f. 132r-132v; 11533, f. 521r-521v; 13104, f. 199v-200r; 13105 , f. $17 r-17 v$, y 13259 , f. $59 v$.

39 Reclaman el cumplimiento de la ordenanza dictada al respecto. Tampoco resulta satisfactoria la simple aceptación por el monarca: en respuesta a la réplica se logra el nombramiento de una comisión integrada por dos procuradores y los contadores para resolver lo que consideren oportuno. Petición décimo octava. Cortes, f. 87. B.N.E. MSS/1220, f. 79v-80r; 10649, f. 310v-311r; 11128, f. 121v-122r; 11533, f. 516r; 13105, f. 11r-11v, y 13259, f. 57r-57v.

40 Recaudadores que no causen molestias innecesarias y cobren efectivamente lo que les es otorgado, evitando pérdidas por mala gestión de su oficio; también fue replicada la respuesta a esta petición, demandando medidas efectivas al respecto. Petición decimonovena. Cortes, III, f. 87-88. B.N.E. MSS/1220, f. 80r-80v; 10649, f. 311r-311v; 11128, f. 122v-123r; 11533, f. 516r-516v; 13105, f. 11v-12r, y 13259 , f. 57v.

41 Se señala, como es evidente, que esta forma de conseguir el arrendamiento exige la obtención, por cualquier medio, de la máxima rentabilidad. Vigésima petición. Cortes, III, f. 88. B.N.E. MSS/1220, f. $80 v-81$ r; 10649, f. 311v-312r; 11128, f. 123r-123v; 11533, f. 516v-517r; 13105, f. 12r, y 13259, f. 57v.

42 Reclaman los procuradores el cumplimiento de las ordenanzas dadas por Enrique III y por el propio Juan II, prohibiendo a judíos y moros ejercer cualquier oficio que les otorgue jurisdicción sobre cristianos, y que se evite cualquier fraude que permita su incumplimiento. La reticente respuesta del monarca suscita, una vez más, una replica solicitando el estricto cumplimiento de las ordenanzas; la respuesta, que promete estudiar las ordenanzas y bulas apostólicas referentes al asunto, no supone un compromiso serio en el sentido requerido. Petición vigésimo primera. Cortes, III, f. 88. B.N.E. MSS/1220, f. 81r-81v; 10649, f. 312r-313r; 11128, f. 123v-124v; 11533, f. 517r-517v; 13105, f. 12r-13r, y 13259, f. 57v-58r.

Debe tenerse en cuenta, además, que el papa Martín V, el 20 de septiembre de 1421, había autorizado a los judíos el ejercicio de la medicina con los cristianos, revocando las penas establecidas en su momento por Benedicto XIII, así como el desempeño de oficios de procuradores, cambistas, arrendadores de rentas y el ejercicio del comercio. Apenas un año antes de la celebración de estas Cortes, el propio Martín V, por bula fechada el 13 de febrero de 1429, ha ratificado aquella autorización a la que une la de disponer de sus propios centros de estudio y culto, el respeto a sus personas y bienes, la autonomía jurídica en sus propios asuntos y el apoyo de la justicia ordinaria para la ejecución de las sentencias dadas en aquellos casos. Estas bulas se incluyen en un privilegio de Juan II, otorgado en Arévalo, a 28 de agosto de 1450, confirmando éstas y otra de Eugenio IV, favorables a las comunidades 
También es preciso que la presión fiscal sea justa y equilibrada. Para ello es necesaria la revisión del censo de fuegos, porque se han producido modificaciones y éstas benefician a algunos núcleos y perjudican severamente a otros ${ }^{43}$, hecho especialmente relevante en lo referente al trasvase de población del realengo a favor del señorío debido a la elevada presión fiscal ${ }^{44}$. Imprescindible resulta, en fin, que quienes han de cobrar de las rentas reales lo hagan en tiempo y lugares adecuados $^{45}$.

Como problema específico se presenta el caso de Castro Urdiales, quizá excepcional por su gravedad, pero reflejo de la difícil situación de las ciudades y villas del reino y ejemplo de los efectos de la guerra y los desequilibrios del censo. La villa se ha visto afectada por mortandades, enfrentamientos internos y dos incendios, y ha sido saqueada por los ingleses; por todo ello su población ha descendido de dos mil a trescientos vecinos, lo que hace imposible que hagan frente a su elevada cabeza de pecho y requiere la adopción de medidas urgentes ${ }^{46}$.

A modo de resumen de todas las peticiones del cuaderno, una última pide que considere la carga a que ha debido hacer frente el reino desde el comienzo de la guerra, en pedido y monedas, en levas de víveres y pertrechos y en los empréstitos ordenados a ciudades y particulares, ahora incrementada con la demanda de un nuevo servicio. La respuesta dada a esta petición no permite augurar muchas esperanzas sobre el anhelado alivio fiscal ${ }^{47}$.

judías castellanas, y revocando otra contraria de Eugenio IV de 1442. Todo ello en traslado obtenido en Medina del Campo el 20 de octubre de 1450. Pub. CASTAÑO GONZÁLEZ, J. «Las aljamas judías de Castilla a mediados del siglo XV: la carta real de 1450", En la España Medieval, 18, 1955, 181-203, en concreto, págs. 194-203. Recogido también por F. SUÁREZ BILBAO, El fuero judiego en la España cristiana. Las fuentes jurídicas, siglos V-XV. Madrid, Dykinson, 2000, págs. 434-443.

${ }_{43}$ Prueba de lo urgente que se considera la medida es que, pese a que el rey acepta la revisión del censo, en réplica se solicita que se vea enseguida y se disponga sobre ello, a lo que asimismo asiente e rey. Petición vigésimo sexta. Cortes, III, f. 90-91. B.N.E. MSS/1220, f. 83v-84v; 10649, f. 316r-317r; 11128 f. $128 v-129 v ; 11533$, f. 519r-519v; 13105 , f. $15 r-15 v$, y 13259 , f. 58v-59r.

${ }^{44}$ La emigración de pecheros del realengo a señorío, buscando una situación fiscal más benigna, hace que los que permanecen tengan que hacer frente a una cabeza de pecho proporcionalmente más elevada. Si no se pone solución se corre el peligro de crear una espiral que despoblaría el realengo. Por eso piden se disponga que quienes lo han abandonado desde primero de enero de 1429 deban pagar pedido y monedas y todos los gravámenes que correspondan por los bienes que hayan dejado en sus antiguos lugares de vecindario. Petición trigésimo cuarta. Cortes, III, f. 94. B.N.E. MSS/1019, f. 21v-22r; 1220 , f. 88v-89r; 6720, f. 31v-32r; 10649, f. 322r-323r; 11128, f. 136v-137v; 11533, f. 523r-523v; 13104 f. $200 v-201$ r; 13105 , f. $19 r-19 v$, y 13259 , f. $60 v$.

${ }_{45} \mathrm{Se}$ trata de que quienes han de percibir dichas cantidades lo hagan efectivamente y no se pierdan éstas en un laberinto de obstáculos y maniobras. Petición vigésimo segunda. Cortes, III, f. 88-89. B.N.E. MSS/1220, f. 81v-82r; 10649, f. 313r-313v; 11128, f. 125r; 11533, f. 517v; 13105, f. 13r, y 13259, f. 58r.

${ }^{46}$ Por todo ello se pide que ordene una quita del pedido o una exención del mismo durante algunos años. Atendiendo a la réplica sobre la respuesta dada a esta petición, por la que se pide la adopción de medidas urgentes, el monarca ordena que el asunto sea visto por los contadores. Petición vigésimo séptima. Cortes, III, f. 91. B.N.E. MSS/1220, f. 84v-85r; 10649, f. 317r-318r; 11128, f. 129v-131r; 11533, f. 519v-520v; 13105, f. 15v-16v, y 13259, f. 59r.

47 Se pide, además, que no exija préstamo a las ciudades que todavía no lo hayan pagado, para evitar la agobiante demanda de recursos. El rey dice haber provisto como cumple a su servicio y ordena 


\section{PREOCUPACIONES URBANAS ANTE LA NUEVA SITUACIÓN.}

Tras las Cortes de Burgos, pese a la decidida voluntad de Juan II y Álvaro de Luna de lograr un enfrentamiento decisivo, no se registran nuevos combates, sino las negociaciones que conducen a las treguas de Majano. Después de su firma, el rey va a Burgo de Osma donde, el 3 de agosto, se hace el alarde y se disuelven las tropas; a continuación, visita al Príncipe en Segovia y a la reina en Madrigal, donde de nuevo convoca Cortes $^{48}$.

El rechazo de los infantes Enrique y Pedro a los acuerdos de Majano y la implicación en esa rebeldía de Juan de Sotomayor, maestre de Alcántara ${ }^{49}$, va a prolongar la guerra en Extremadura y exige la proximidad del rey, que va a Salamanca al frente de un importante contingente armado; en esta ciudad se celebran las Cortes que estaban convocadas ${ }^{50}$.

Aunque, al decir de la Crónica, las ciudades reciben de modo muy favorable la petición de nuevo servicio para la guerra con los $\operatorname{moros}^{51}$, la realidad parece muy distinta, como es lógico visto el ambiente de las anteriores sesiones. Fue precisa una dura negociación con los procuradores que Juan II encomendó a algunos miembros del Consejo y a los Contadores mayores: el otorgamiento no se realizó hasta mediados de noviembre, estando ya en Fuentesaúco ${ }^{52}$. El cuaderno se data en Palencia, el 20 de enero de 1431, a donde el rey ha acudido, entre otras cosas para asistir a la boda de Álvaro de Luna con Juana Pimentel, acto que constituye una auténtica constitución de la oligarquía que va a gobernar Castilla en los próximos años ${ }^{53}$.

el cumplimiento de las disposiciones dadas al efecto. Cuadragésima petición. Cortes, III, f. 97. B.N.E. $\mathrm{MSS} / 1220$, f. $91 \mathrm{v}-92$ r; 10649 , f. 326v-327v; 11128, f. 142r-143r; 13105 , f. $22 \mathrm{v}$ y 13259 , f. $61 \mathrm{v}$.

${ }^{48}$ Crónica, 1430, c. 23, p. 487-488. Pedro Carrillo de Huete. Crónica del halconero de Juan II. Ed. J. de M. CARRIAZO ARROQUIA. Granada 2006 (ed. facsímil). (Halconero), p. 57. Probablemente la convocatoria se hace el día 2 de septiembre, durante su breve estancia en esta villa. Itinerario, p. 257

${ }^{49} \mathrm{Me}$ he ocupado de la actuación de Juan de Sotomayor y, consecuencia de ella, de su sustitución al frente de la Orden por su sobrino Gutierre de Sotomayor en «Gutierre de Sotomayor: protagonismo político del Comendador Mayor de Alcántara», Comendas das Ordens Militares na Idade Média. Militarium Ordinum Analecta. Fontes para o estudo das Ordens Religioso-Militares, 11, 2009, 217-231. («Gutierre de Sotomayor»).

50 Crónica, 1430 , c. $25-26$, p. 488-489. Las sesiones de estas Cortes, que conocemos como de Palencia de 1431, por datarse en esta ciudad su cuaderno, se desarrollan en Salamanca, donde el rey pasa los meses de septiembre y octubre de 1430, Itinerario, p. 257-258. y Fuentesaúco, en el mes de noviembre, que es donde se realiza el otorgamiento. Crónica, 1430, c. 26 y 29, p. 489-490.

51 «...los procuradores respondieron muy graciosamente, diciendo que todo se haría conforme Su Merced mandase, ofreciendo a las ciudades e villas que los habían embiado, e quanto en el mundo tenían para su servicio, para cumplir sus menesteres en guerra tan justa como a él placía de hacer contra los moros ..." Aún así se otorgaron 45 cuentos en quince monedas y pedido y medio. Crónica, 1430 , c. 26, p. 489.

${ }^{52}$ Crónica, 1430 , c. 29 , p. 490. La negociación hubo de ser dura, aunque las peticiones del cuaderno no registran réplicas como había sucedido en Burgos.

${ }^{53}$ La boda tiene lugar en Calabazanos, Palencia, el sábado 27 de enero de 1431. Fueron padrinos el propio Juan II y Leonor, esposa del Adelantado Pedro Manrique, que aparece como hombre fuerte del momento. LOPE BARRIENTOS. Refundición de la Crónica del Halconero, ed. J. de M. CARRIAZO. 
La mayor parte de las peticiones de las Cortes de Palencia ${ }^{54}$ reiteran algunas de las ya contenidas en el Cuaderno de Burgos. Son las que pretenden impedir la corrupción en el reclutamiento de tropas: número, puntualidad ${ }^{55}$ y adecuada retribución ${ }^{56}$; las que tratan de evitar que se repitan problemas ya denunciados, como las levas de víveres y pertrechos ${ }^{57}$, y el reclutamiento de labradores ${ }^{58}$, o tratan de cerrar los que todavía no han sido resueltos, como la devolución de los préstamos exigidos a instituciones religiosas ${ }^{59}$ y particulares ${ }^{60}$, el pago de indemnizaciones y retribuciones debidas ${ }^{61}$, o la cancelación de todo requerimiento de préstamos, nueva petición en la línea de liquidación de la pasada política62.

Madrid, Espasa Calpe, 1946. (Refundición), c. 56, p. 104-105. Juana Pimentel es hija de Rodrigo Alfonso Pimentel, conde de Benavente, y de su esposa Leonor Enríquez de Mendoza; sus vínculos familiares conectan entre sí a los más importantes linajes: Pimentel, Mendoza, Manrique, Enríquez, Velasco, Osorio, Arellano, etc. Halconero, c. 63, p. 75-76.

${ }_{54}$ Algunas consideraciones sobre el cuaderno de estas Cortes, y de las restantes hasta 1444, en César OLIVERA SERRANO, "Las Cortes de Castilla y el poder real (1431-1444)», En la España Medieval, 11, 1988, 223-260, («Cortes y poder»), en concreto págs. 224-227.

55 Petición primera, que reitera de modo casi idéntico la misma petición de las Cortes de Burgos, en este caso en relación con la guerra de Granada; la petición segunda, como la de aquellas Cortes, requiere castigos severos para quien realice más de un alarde. Cortes, III, f. 98-99. B.N.E. MSS/1220, f. 93r-94r; 10649, f. 332r-333r; 11128, f. 146r-147r; 11533, f. 526v; 13105, f. 41v-42r, y 13259, f. 66r-66v.

${ }^{56}$ Petición tercera. Como en la misma petición de la sesión anterior, se señalan lo peligroso que resultan tropas mal pagadas o sometidas a precios abusivos. En esta ocasión se nombra jueces para despachar adecuadamente este asunto a Rodrigo Alfonso Pimentel, conde de Benavente, Garci Fernández Manrique, conde de Castañeda, y Fernando Díaz de Toledo, oidor, referendario y relator Cortes, III, f. 99. B.N.E. MSS/1220, f. 93r-94v; 10649, f. 333r-333v; 11128, f. 147r-147v; 11533, f. 526v-527r; 13105 , f. 42r-42v, y 13259 , f. $66 \mathrm{v}$.

57 Petición cuarta, repetición de las cortes anteriores. Cortes, III, f. 99. B.N.E. MSS/1220, f. 94v; 10649, f. 333v-334r; 11128, f. 147v-148r; 11533, f. 527r; 13105, f. 42v, y 13259, f. 66v.

${ }_{58}$ Petición quinta, reiteración de la séptima de la sesión anterior, a la que se había dado una respuesta evasiva, pese a la réplica entonces realizada. La respuesta, los excusará en cuanto sea posible, resulta ahora aún mas vaga. Cortes, f. 99. B.N.E. MSS/1220, f. 94v-95r; 10649, f. 334r-334v; 11128, f. 148r-148v; 11533, f. 527r; 13105, f. 42v; 13259, f. 66v.

59 Petición sexta. En las peticiones 8 y 9 de Burgos se contenía un debate sobre si se había tratado de préstamos o tomas y las condiciones para pedir aquéllos. Ahora se pedía la simple devolución; el monarca responde que ordena a los contadores mayores que busquen lugar adecuado para efectuar pago inmediato. Cortes, III, f. 99-100. B.N.E. MSS/1220, f. 95r; 10649, f. 334v-335r; 11128, f. 148v-149r; 11533 , f. 527r-527v; 13105, f. 43r, y 13259, f. 66v-67r.

${ }^{60}$ Como en el caso anterior, se pide la devolución inmediata. Petición séptima, similar a la décima de las Cortes de Burgos. Cortes, III, f. 100. B.N.E. MSS/1220, f. 95r-95v; 10649, f. 335r-335v; 11128, f. 149r-150r; 13105, f. 43r-43v, y 13259, f. 67r.

${ }^{61}$ La petición decimoquinta de Burgos requería el pago de las indemnizaciones por los daños investigados hasta ese momento. Ahora, la petición décima pide que, además de aquellas reparaciones, se atiendan las relativas a los daños causados tanto por las tropas que estaban con el rey como por las de los fronteros, todos los cuales, al parecer, han sido puestos en descuento. Se ordena a los contadores mayores que despachen de inmediato el asunto. Cortes, III, f. 101. B.N.E. MSS/1220, f. 96v-97r; 10649, f. 337r-337v; 11128, f. 151v-152v; 13105, f. 44r-44v, y 13259, f. 67v. En esa línea, la petición duodécima, reiterando la vigésimo segunda de Burgos requiere el pago puntal a vasallos y naturales, por tercios del año, en sus lugares de residencia. Cortes, III, f. 101-102. B.N.E. Ibid. f. 97v; $338 \mathrm{r}-338 \mathrm{v} ; 152 \mathrm{v}-153 \mathrm{r}$; $45 \mathrm{r}$ y $67 \mathrm{v}$, respectivamente.

62 Se pide que se revoquen todas las credenciales otorgadas a diversas personas para requerir los préstamos y que no sen den en el futuro, salvo a personas respetables. Accede el rey, excepto las otorgadas a los capitanes en frontera de moros, en el territorio bajo su mando. Petición octava. Cortes, III, f. 100-101. B.N.E. MSS/1220, f. 95v-96r; 10649, f. 335v-336v; 11128, f. 150r-151r; 13105, f. 43v-44r, y 13259 , f. 67 r. 
Sigue siendo objeto de preocupación para los procuradores la conservación de las libertades y privilegios de las ciudades, tanto en la designación de procuradores $^{63}$ o el nombramiento de recaudadores ${ }^{64}$, cuestiones ya planteadas en las sesiones anteriores, y otras que la situación mostraba imprescindibles, como la obtención de respuestas a las peticiones de cada una de las ciudades ${ }^{65}$ y que lo respondido se lleve a cabo efectivamente, para lo que se requiere que se le otorgue fuerza de ley ${ }^{66}$.

El gran esfuerzo fiscal al que el reino viene haciendo frente en los últimos meses exige, insisten de nuevo los procuradores, un justo reparto de las cargas ${ }^{67}$, que nadie pueda eludir sus responsabilidades fiscales, de lo que resulta especialmente revelador el caso de Galicia en estos dos últimos años ${ }^{68}$, pero también que se atiendan, antes de proceder a imponer castigos, las razones que pueden justificar que determinadas personas no hayan respondido adecuadamente al llamamiento militar 69 .

Un problema que afecta de modo muy sensible a la recaudación de fondos es la proliferación de personas exentas de impuestos reales y contribuciones concejiles. Las situaciones recogidas en la correspondiente petición de las Cortes, y en la documentación manejada en esta ocasión, son las relativas a los excusados,

63 Petición novena, que repite casi literalmente la decimotercera de Burgos; se pide que las ciudades designen libremente a sus procuradores y que éstos no sean labradores, sesmeros o pecheros, por razones de dignidad y eficacia en las sesiones. La respuesta asegura que no ha habido intromisión regia en tales designaciones y que se respetará la costumbre. Cortes, III, f. 101. B.N.E. MSS/1220, f. 96r-96v; 10649, f. 336v-337r; 11128, f. 151r-151v; 13105, f. 44r, y 13259, f. 67r-67v.

64 Petición undécima, similar a la decimonovena de las Cortes de Burgos: que sean personas llanas y abonadas que ejerzan bien su misión sin presiones innecesarias, cohechos ni baratos. Cortes, III, f. 101. B.N.E. MSS/1220, f. 97r-97v; 10649, f. 337v-338r; 11128, f. 152v; 13105, f. 44v-45r, y 13259, f. 67v.

${ }^{65}$ Petición décimo séptima. Responde el rey que las entreguen enseguida y serán rápidamente contestadas. Cortes, III, f. 103. B.N.E. MSS/1220, f. 99v; 10649, f. 341v; 11128, f. 156v-157r; 13105, f. 47r, y 13259, f. 68v.

66 Petición décimo octava. Se formula ahora con carácter general una petición que acompaña habitualmente a cada una de las presentadas por los procuradores. Si se cumpliera, otorgaría un gran poder a las Cortes, al convertir en leyes todas las respuestas a sus peticiones. Cortes, III, f. 104. MSS/1220, f. 99v; 10649, f. 341v-342r; 11128, f. 157r-157v; 13105, f. 47r-47v, y 13259, f. 68v.

67 Petición decimotercera. Se hace imprescindible un nuevo censo y la corrección del repartimiento, como ya pidieran en Burgos, petición vigésimo sexta. Cortes, III, f. 102. B.N.E. MSS/1220, f. 97v-98r; 10649, f. 338v-339r; 11128, f. 153v-154r; 13105, f. 45r-45v, y 13259, f. 68r. En ese mismo sentido se expresa la petición décimo sexta, idéntica a la vigésimo quinta de las Cortes de Burgos, por las que se pide que ninguna feria o mercado estén exentos de alcabala. Cortes, III, f. 103. B.N.E. MSS/1220, f. 99r-99v; 10649, f. 340v-341v; 11128, f. 155v-156v; 13105, f. 46v-47r, y 13259, f. 68r-68v.

68 Denuncian los procuradores, petición décimo cuarta, que el reino de Galicia no ha pagado lo que le ha correspondido en el pedido de estos dos últimos años, 1429 y 1430. Cortes, III, f. 102. B.N.E. MSS/1220, f. 98r-98v; 10649, f. 339r-339v; 11128, f. 154r-154v; 13105, f. 45v-46r, y 13259, f. 68r. El escandaloso hecho es indudablemente consecuencia de los contactos del adelantado de Galicia, Diego Sarmiento, con los Infantes, lo que motivará la prisión del Adelantado, como veremos, primer paso para la solución del problema a la que se compromete el rey en este momento y que será atendido en la siguiente sesión de Cortes. La prisión del Adelantado en Halconero, p. 113.

69 Los procuradores, que siempre reclaman medidas estrictas, piden ahora audiencia previa a los amenazados de confiscación; entre las posibles eximentes se menciona no haber recibido el pago correspondiente. Petición décimo quinta. Cortes, III, f. 102-103. B.N.E. MSS/1220, f. 98v-99r; 10649, f. $339 v-340$ r; 11128 , f. $154 v-155 v ; 13105$, f. 46r-46v, y 13259, f. 68 r. 
designados por laicos y eclesiásticos poderosos, concejos y otras entidades, que no están asentados en los libros de lo salvado o que, estándolo, solo deberían estar exentos del pago de monedas, pero no del resto de gravámenes; las propiedades que habiendo pertenecido a pecheros han sido trasferidas a exentos; y los pecheros que, por haber sido armados caballeros, pretenden gozar de la totalidad de los privilegios propios de éstos ${ }^{70}$.

En su respuesta a las Cortes, Juan II ordena que se cumplan las disposiciones adoptadas por Juan I, ratificadas y ampliadas por Enrique III, incluye nuevas limitaciones a la exención y confirma sus propias disposiciones anteriores sobre esta materia. En el tenso ambiente de las Cortes de Segovia, en noviembre de 1386, habían pedido los procuradores que no hubiera otra exención de tributos excepto la de quienes figurasen de modo expreso en el cuaderno de monedas ${ }^{71}$; en respuesta a esta petición, en abril del año siguiente, Juan I había ordenado que todos, excepto caballeros, hidalgos, dueñas o doncellas, paguasen en todos los pechos, servicios y empréstitos, reales o concejiles, y declaraba nulo todo privilegio de exención, salvo en monedas ${ }^{72}$.

El pedido y servicio requerido por Enrique III al reino, en 1397, suscitó numerosos pleitos y recursos porque el monarca, apelando a la doctrina jurídica establecida por Juan I en las Cortes de Briviesca, confirma el documento anterior de su padre y ordena que sea observado en el servicio y pedido de los años pasado y actual, y en el futuro ${ }^{73}$. En consecuencia, dispone que, salvo los citados, ningún privilegio otorgado por los monarcas anteriores sea guardado sino en lo relativo a monedas; que, por tanto, los excusados por privilegio, los caballeros de alarde, monteros, monederos, escribanos de corte y de ciudades y villas, y los excusados de iglesias, monasterios, oficiales y caballeros pechen en todos los tributos tanto reales como concejiles. Se establecen severas penas para quienes reclamen que se les guarde aquella exención y para las justicias que no apliquen esta disposición, y se declaran exceptuados de ella a caballeros e hidalgos del arzobispado

70 Petición décimo novena. Cortes, III, f. 104-113. B.N.E. MSS/1220, f. 100r-115r; 6720, f. 33r-36v; 10649 , f. 157v-182r; 13105, f. 47v-48r, y 13259, f. 69r-74v. Se aprecian algunas variantes entre los distintos manuscritos: el 6720, que solo contiene esta petición del cuaderno, la divide en tres, y omite, como el 11128 el documento de Juan II de 20 de enero de 1431, considerándolo como la propia respuesta real a la petición de los procuradores. El ms. 13259 divide la petición en cuatro, a las que atribuye los números 19, 20, 21 y 22. De todo ello damos detalle en el lugar oportuno.

71 La amargura por el reciente desastre de Aljubarrota y la amenaza que supone la invasión Lancaster, requieren el alegato de legitimidad contenido en el discurso real y las cesiones que fue preciso hacer a las Cortes; eliminar exenciones, dadas las perentorias necesidades económicas, era imprescindible. Vid. SUÁREZ FERNÁNDEZ, L. Historia del reinado de Juan I de Castilla. Madrid 1977. (Juan I). Vol. I, p. 253-256.

72 1387, abril, 19. Salamanca. En todos los manuscritos, incluyendo el texto publicado por la R.A.H., se data este documento en 1397; la fecha, indiscutiblemente errónea, debe ser corregida por la que aquí proporcionamos. El itinerario del rey le sitúa en Salamanca en los meses de abril y mayo de ese año. SUÁREZ FERNÁNDEZ, L. Juan I, vol. I, p. 408-409.

73 1398, febrero, 28. Toledo. Enrique III considera esta decisión obra de las Cortes de Briviesca, aunque como hemos visto la decisión ya se había tomado con anterioridad. 
de Sevilla, de los obispados de Córdoba y Jaén y de las demás ciudades donde acostumbran pagar, donde seguirá aplicándose la normativa habitual ${ }^{74}$.

Ahora, Juan II ratifica estas disposiciones y ordena su cumplimiento, extiende las sanciones a quienes designen excusados, amplía la pena pecuniaria a quienes pretendan excusarse e incluye nuevas medidas contra las justicias poco diligentes ${ }^{75}$. Además, dicta ahora una nueva disposición relativa a los bienes inmuebles de pecheros que, al ser enajenados a favor de personas o entidades privilegiadas, francas o exentas, pretenden éstos ser excusados de contribuir por estos bienes en pechos y derechos reales y concejiles; es una vía de escape que, aún sin tratarse de maniobras fraudulentas, supondría un severo quebranto a las respectivas haciendas. Dispone que todos los bienes inmuebles de pecheros, de realengo, abadengo, behetría, o señorío, queden sujetos a tributación, independientemente de la condición de su propietario, y no puedan ser transmitidos sino con esta condición ni excusarse en forma alguna, bajo las penas oportunas ${ }^{76}$.

Casi un año después este acuerdo de Cortes, firma Juan II un documento en términos similares, bajo idénticas sanciones, vinculando las cargas fiscales al bien, independientemente de la condición de su nuevo propietario, sea cual fuere el modo de trasmisión: sucesión, con o sin testamento, legado, donación, permuta o venta ${ }^{77}$.

Asimismo, confirma Juan II dos disposiciones suyas anteriores sobre este asunto, una de 1422 y otra de hacía pocos meses. Por la primera de ellas había ordenado que todos los pecheros, que habían sido armados caballeros desde el comienzo

74 La sanción será de mil maravedís cada vez que se reclame la exención: un tercio para la cámara real, otro para la ciudad o villa en que ocurra y otro para el acusador; ordena a la justicia del lugar, so pena de igual sanción, que prende de oficio al infractor y retenga para sí el tercio correspondiente al acusador. Los insolventes cumplirán cadena, dos meses la primera vez, cuatro la segunda, seis la tercera y perpetua en la siguiente ocasión.

75 Quienes excusen, pagarán los pechos de los excusados con las setenas; quienes pretendan ser excusados pagarán el doble del importe del pecho del que quisieren excusarse; las justicias incurrirán en privación de oficios, además del pago de los pechos con las setenas.

Con fecha 1431, febrero, 6. Palencia, firma Juan II una pragmática ratificando los mencionados documentos de Enrique III y Juan I, que inserta, ordenando el cumplimiento de esta petición de las Cortes. En este caso se sanciona a quien pretenda estar exento a pagar el doble de la exención pretendida y a los justicias que no lo hagan cumplir con la privación de oficio y el pago de los pechos con las setenas; ordena que se asiente en los cuadernos de monedas y que se den las cartas necesarias para su ejecución. B.N.E. MSS/ 1019, f. 24r-24v; 10649, f. 373r-382v; 11132, f. 73v-83r, y 13259, f. 63v-66r. Con algunas variantes y desorden en la foliación, MSS/1019, f. 30r-31v y continuación en f. 23r-23v.

76 El ms. 6720 de la B.N.E. f. 36v, incluye esta disposición de Juan II como petición segunda, de las tres que únicamente incluye; igualmente el ms. 13259, f. 71r-72v, lo incluye como petición vigésima de cuaderno. La sanciones previstas son, para las justicias que no lo hagan cumplir, privación de oficio y 20.000 maravedís a cada uno. Ordena, bajo las mismas penas, que los alcaldes, merinos y otros oficiales hagan inventario ante notario de todos los bienes raíces de pecheros, para que se sepa, y se guarde en las arcas de los concejos; que cada recaudador lo haga publicar en su recaudamiento, lo tome por testimonio y lo envíe al rey, y que los escribanos lo den signado sin cobrar.

77 1431, diciembre, 22. Zamora. B.N.E. MSS/10649, f. 366r-372r; 11132, f. 67v-73r; 13105, f. 60r-63v, y 13259, f. 62r-63v. La fecha del mes la proporciona el ms. 11132; en el resto no se indica. Juan II pasó, en efecto el mes de diciembre de 1431 en Zamora. Itinerario, p. 268. 
del reinado, incluida la etapa de minoría, queden sujetos al pago de todos los pechos reales y concejiles, como lo estaban antes de dicha investidura, no obstante cualquier privilegio expedido por él o por sus tutores, todos los cuales declara derogados en lo que atañe a este asunto. No obstante, seguirán gozando de todos los privilegios, exenciones y prerrogativas que corresponden a los caballeros. Ordena se apremie al pago a estos caballeros y a sus hijos habidos con anterioridad a la investidura como caballeros, que igualmente quedan sujetos a esta carga ${ }^{78}$.

La segunda disposición, ahora confirmada, había respondido a la información de que el canciller mayor, el escribano mayor y su lugarteniente habían otorgado privilegios de exención de pedidos y tributos a algunos ballesteros de los cinco de cada lugar; por ella había ordenado a aquellos oficiales, bajo pena de privación de oficios y confiscación de bienes, que no concedan este privilegio, ni otra exención alguna, a aquellos ballesteros ni a cualesquier otros, ni a oficiales que no tengan del rey tierra ni ración, y que escriban a las ciudades y villas, de las que son vecinos los oficiales y ballesteros beneficiados por tales franquezas, para que no les sean guardadas, porque es voluntad regia que únicamente los ballesteros de los cinco gocen de exención de monedas, solamente, por lo que irán puestos por salvados en los cuadernos que serán entregados en su momento a los arrendadores de este impuesto ${ }^{79}$.

\section{UNAS NUEVAS BASES INSTITUCIONALES.}

Pese a las dificultades del momento y las graves preocupaciones del reino, que se traslucen en los cuadernos de Cortes, el gobierno de la oligarquía comienza pronto a obtener algunos éxitos importantes. Son vitales para los mercaderes castellanos los obtenidos en el ámbito atlántico: el restablecimiento, ya desde octubre de 1429, por el duque de Borgoña, de los privilegios de aquéllos en Flandes; la firma de un acuerdo con el duque de Bretaña, en mayo de 1430, que otorga privilegios a los castellanos en este ducado; sobre todo, la firma con Inglaterra, el 8 de noviembre de 1430, de un acuerdo de libertad de comercio y una tregua anual renovable ${ }^{80}$.

78 1422, diciembre, 20. Toledo. Obtener la caballería como medio de eludir el pago de pechos reales y concejiles causa graves quebrantos a la hacienda real y a los concejos que han de hacer frente a las cargas que correspondían a los nuevos caballeros. El ms. 6720 de la B.N.E., f. 38v incluye esta disposición como petición tercera del cuaderno. En cuanto al ms. 13259 de esta misma biblioteca, f. $72 \mathrm{v}-73 \mathrm{v}$, la considera la vigésimo primera petición.

Copia de este documento de 1422 en B.N.E. MSS/1019, f. 6r-7r; 13104, f. 102r-104v, y 13259, f. 35r-35v.

79 1430, septiembre, 15. Salamanca. En el ms. 13259 de la B.N.E., f. 73v-74r, figura esta disposición como petición vigésimo segunda de este cuaderno. Copia de esta disposición que confirma el vigor de la mencionada pragmática de septiembre, con fecha 1431, enero, 20. Palencia, en B.N.E. MSS/1019, f. $23 v$ y $25 r-25 v$.

80 SUÁREZ FERNÁNDEZ, L. “Los Trastámara de Castilla y Aragón en el siglo XV», Historia de España. Tomo XV. Madrid, Espasa Calpe, 1964, p. 1-318. («Los Trastámara»). Sigue constituyendo el más completo análisis de los acontecimientos de la época. Vid. p. 127-128. 
Éxitos también en la guerra con Granada, que se mantendrá con diferente intensidad a lo largo de todo el gobierno de la oligarquía; las dificultades internas impiden éxitos mayores, pero la destrucción del sultanato constituyó un auténtico objetivo, iniciado en el mismo real de Majano ${ }^{81}$. No se trata solo de un argumento perfecto para la obtención de recursos, sino de una acción sostenida que permite algunos avances, causar daños importantes al reino de Granada, una victoria, La Higueruela, no meramente simbólica, o la imposición de un protectorado, a pesar de lo efímero del mandato de Yusuf IV; son las divisiones internas, que afloran en esta misma expedición las que obligan a detener las operaciones ${ }^{82}$.

Claro objetivo siempre de la política de Álvaro de Luna, el logro de la paz con Portugal, que venía constituyendo objetivo preferente de Juan I de Portugal desde hacía muchos años, supone un éxito para ambas partes. Como colofón de un largo proceso diplomático, el 30 de octubre de 1431, en Medina del Campo, se firmaba la paz con Portugal, para lo que fue preciso superar rencores todavía vivos por la tragedia de Aljubarrota; paz imprescindible, pero sometida a graves amenazas ${ }^{83}$ A esos éxitos viene a sumarse la brillante actuación de los diplomáticos castellanos en el concilio de Basilea, donde van a mostrarse como firmes defensores de la autoridad pontificia, en la línea ya protagonizada por Castilla en el concilio de Constanza, contrapeso a las intrigas favorables a la rebeldía conciliar de Alfonso $\mathrm{V}$, y hábiles defensores de los intereses castellanos ${ }^{84}$.

${ }^{81}$ La no renovación de treguas tuvo repercusión inmediata, con entradas en tierras granadinas, en particular la de Diego de Ribera, Adelantado Mayor de Andalucía, acompañado entre otros de Egas, señor de Luque y su hijo García, poco después detenidos, y García Sarmiento, hijo de Diego Sarmiento, Adelantado de Galicia. Crónica, 1430, c. 27 y 28, p. 489. Halconero, c.69. Refundición, c. 55.

82 Halconero, dedica a las operaciones contra Granada en 1431 los capítulos 80, 81, 82, 88, 89, 90, 91, 92, 93, 107, 108, y 109. Crónica, 1431, c. 11, 18, 19, 20, y 21. Crónica de don Álvaro de Luna, ed. J. de M. CARRIAZO, Madrid, Espasa Calpe, 1940. (D. Álvaro), c. 35-38. Da cuenta de las peligrosas divisiones, surgidas en la propia Vega, Halconero, c. 94. Crónica, 1431, c. 21, p. 500-501, da como razón del fin de la campaña las dificultades de abastecimiento, las divisiones internas, que considera principal razón, y la compra de la voluntad de Álvaro de Luna por los granadinos. D. Álvaro, c. 39 explica las divisiones como resultado de la envidia que suscitan las hazañas del condestable y el favor del rey, afirma la existencia de planes para asesinarle e implica en ellos a Pedro Fernández de Velasco, Iñigo López de Mendoza, Gutierre Gómez, obispo de Palencia, Fernán Álvarez, y otros, conjura que se habría tejido ya antes de la partida del rey de Córdoba y de la que éste y su condestable tuvieron oportuna noticia.

Me parece indudable que hubo una respuesta militar menor de lo esperado, fruto de la división interna de Castilla, como han denunciado las Cortes de Palencia de 1431, factor que hubo de pesar en el acortamiento de la campaña.

${ }^{83}$ He dedicado un trabajo a ese proceso diplomático y a las dificultades que hubo de superar: «El restablecimiento de la paz entre Castilla y Portugal 1402-1431», en Ibéria: Quatrocentos/Quinientos. Duas décadas de cátedra (1984-2006). Homenagem a Luis Adao da Fonseca. HOMEN, A. L de CARVALHO, PIZARRO, J.A. de SOTTO MAYOR, y PINTO, P.M. de CARVALHO (Coords). Porto, Civilizaçao Editora, 2009, págs. 47-90. Sobre las amenazas contra esta paz, veáse mi artículo, «Medina del Campo-Almeirim: una paz anhelada y permanentemente amenazada», en Relaçoes históricas Portugal-Espanha. Partilha e fronteira. Populaçao e Sociedade. Revista del Centro de Estudos da Populaçao, Economía e Sociedade, CEPESE, 17, 2009, 61-84. («Medina del Campo-Almeirim»).

84 Sobre la actuación castellana en Basilea, véase mi trabajo La situación europea en época del Concilio de Basilea. El informe de la embajada del Reino de Castilla. León, Centro de Estudios e Investigación San Isidoro, 1992. 
También se producen algunos acontecimientos que denotan resistencias importantes, erradicadas de modo contundente; en ocasiones están protagonizados por partidarios de los Infantes de Aragón, hecho que se entiende fácilmente ${ }^{85}$, pero otros movimientos no tienen esa justificación y hacen pensar en desacuerdos entre la oligarquía gobernante y don Álvaro por la forma en que éste entiende el ejercicio del poder. Son circunstancias a tener en cuenta para entender adecuadamente el sentido de las peticiones presentadas.

Tiene fácil explicación la decisión respecto a Diego Gómez de Sandoval, conde de Castro, abiertamente partidario de Juan de Navarra, convocado por Juan II ante su presencia, con la esperada reacción de su huída y consiguiente juicio y condena ${ }^{86}$. Otros casos resultan menos evidentes, como el juicio y ejecución del contador Sancho Fernández ${ }^{87}$; o la prisión de Egas, señor de Luque, de su esposa y de sus dos hijos, así como de un veinticuatro de Córdoba, a comienzos de mayo de 1431, sin duda a instancias de don Álvaro ${ }^{88}$.

En octubre de 1431, durante la celebración en Medina del Campo de las sesiones de Cortes, que conocemos como Cortes de Zamora de 1432, se produce la espectacular detención de Diego Sarmiento, adelantado de Galicia, realizada por Álvaro de Luna y el almirante, Fadrique Enríquez ${ }^{89}$. Su detención está motivada por sus contactos con Juan de Navarra y, sin duda consecuencia de ello, por el impago por Galicia de sus obligaciones fiscales, denunciado en el cuaderno de las Cortes de Palencia de este año ${ }^{90}$. De hecho, a raíz de su detención son convocados cuatro representantes de las ciudades y villas gallegas para que acudan a

${ }^{85}$ En febrero de 1430 se había procedido al despojo de los Infantes de Aragón, hecho que había inducido a Alfonso $\mathrm{V}$ a un último intento bélico ese año; los beneficiarios de la distribución de estos bienes, don Álvaro en primer lugar, integran la nómina de la oligarquía que gobierna durante estos años. SUÁREZ FERNÁNDEZ, L. «Los Trastámara», p. 115. Se completa, en enero del año siguiente, privando al infante Enrique del Maestrazgo de Santiago, en dramática ceremonia celebrada en el convento de Uclés. Halconero, c. 70.

${ }^{86}$ Convocatoria, huída, proceso y condena del conde de Castro, entre diciembre de 1430 y noviembre de 1431, aparecen relatadas en Halconero, c. 60, 65-69, 104 y 105; Refundición, c. 56-59.

87 Ejecutado en Burgos en mayo de 1430. Había sido contador por Fernán Alonso de Robles, contador mayor, que morirá en prisión en agosto de este año. Halconero, c. 68.; la querella contra él fue presentada por Diego González Franco, contador mayor y hombre muy próximo a don Álvaro. Halconero, c. 45-47.

${ }^{88}$ Halconero, c. 78. Refundición, c. 62. Egas figura entre los participantes destacados en una acción contra Colomera, en noviembre de 1430, poco después de extinguidas las treguas con Granada. Con ellos combatió García Sarmiento, capitán de las tropas de Diego Sarmiento, adelantado de Galicia. Halconero, c. 69; Refundición, c. 62; Crónica, 1430, c. 27, p. 489.

${ }_{89}$ Al conocer Juan II que Diego Sarmiento se halla en Mucientes, partió de Medina a las tres de la madrugada y al amanecer había recorrido los 55 kilómetros que, aproximadamente, separan ambas poblaciones, lo que muestra su precipitado interés por capturar al Adelantado. Sin embargo, no pudo hallarlo, aunque sí lograron detenerle los comisionados regios en Palazuelo de Vedija, localidad próxima a Medina de Rioseco, también de su señorío. Halconero, c. 101; Refundición, c. 68.

$90 \mathrm{El}$ asunto del adelantado de Galicia tuvo la mejor solución posible: llevado prisionero en pos del rey, primero a Medina del Campo y luego a Zamora, donde concluyen las Cortes, fue luego trasladado a Castronuño, pero, por orden regia, se le devolvieron sus rentas y posesiones y fue sobreseído el proceso iniciado contra él. Con toda probabilidad, la correcta resolución del problema gallego tuvo que ver con el destino del Adelantado. Además, como recoge la crónica, el hecho de estar casado con una hija de 
Ponferrada a dar explicaciones acerca de su actitud en esta materia ${ }^{91}$. De la trascendencia y amplitud del problema gallego da idea el hecho de que, antes de concluir estas Cortes, ya en Zamora, en enero de 1432, estos procuradores y los prelados y grandes de Galicia juraron al príncipe Enrique, porque no lo habían hecho en el momento que lo hizo el resto del reino ${ }^{92}$.

Pocos días después de la conclusión de las Cortes se produce la detención de Pedro Fernández de Velasco, conde de Haro; don Gutierre Gómez de Toledo, obispo de Palencia, y su sobrino Fernán Álvarez de Toledo, señor de Valdecorneja, Fernán Pérez de Guzmán, primo del obispo palentino y Garcí Sánchez de Alvarado. Los detenidos tendrán suerte diversa: algunos, como el conde de Haro, liberado inmediatamente, otros permanecerán en arresto hasta el mes de septiembre ${ }^{93}$. Lo que resulta de mayor interés es conocer la causa de su detención, sea haber conspirado contra el Condestable en el curso de la campaña de Granada, mantener contactos con los reyes de Aragón y Navarra, una excusa siempre invocada ante cualquier resistencia, o, acaso, encabezar una incipiente oposición a la obra de gobierno de don Álvaro, incluyendo las resistencias a que hubo de imponerse para llegar a un tratado de paz con Portugal ${ }^{94}$.

La detención del infante don Pedro, en agosto de este mismo año ${ }^{95}$, que precipita el fin de la resistencia de los Infantes de Aragón en Extremadura, y la sustitución de Juan de Sotomayor como maestre de Alcántara, en la primera quincena de agosto ${ }^{96}$, vienen a completar el panorama del momento.

Las denominadas Cortes de Zamora habían sido convocadas en el propio real en la Vega de Granada en los primeros días de julio; inician sus sesiones en Me-

Diego López de Estúñiga, hermano de Pedro de Estúñiga, conde de Ledesma, que intercedió por él, pesó en las decisiones tomadas al respecto. Halconero, c. 119-120; Refundición, c. 73.

91 Halconero, c.103.

92 Crónica, 1432, c. 3, p. 503-504. En esta ocasión el rey comunica dos recientes leyes: la primera, prohibiendo que quien tenga oficio del rey en Galicia viva con señor alguno; la segunda, disponiendo pena de muerte para el escudero o peón que coheche a algún ciudadano o labrador y prohibiendo dar acogida a los cohechadores. Halconero, c. 112. En esta ocasión prestaron también juramento Lope de Mendoza, arzobispo de Santiago, y Álvaro de Isorna, obispo de Cuenca.

93 Halconero, c. 114. Refundición, c. 72-73. Crónica, 1432, c. 4, p. 504. CODOIN, 100, c. III, p. 335-337.

94 La razón de estas detenciones la proporciona la Crónica de don Álvaro, c.39, que atribuye la liberación de los detenidos a la intercesión del propio Condestable. También estaba implicado en estos hechos Iñigo López de Mendoza, que permaneció encastillado durante los meses que duró el arresto de los detenidos, don Álvaro, c. 40. Sin embargo, en Crónica, 1432, c. 4, p. 504, se habla de contactos con los reyes de Aragón y Navarra, aunque la propia crónica parece poner en duda la veracidad de esta información.

Es muy probable que la decisión de liberar a los detenidos parta de don Álvaro, y que no sea simplemente una afirmación partidista de fuente tan favorable al Condestable: una vez detenido el infante Pedro, resuelta la situación de Extremadura, y con ello cerrada una posible causa de perturbación de la paz con Portugal, y hecha la demostración de fuerza, convenía una reconciliación con tan importante grupo nobiliario.

95 Halconero, c. 128-129; Refundición, c. 76.

96 Crónica, 1432, c. 14, p. 509-510. Crónica, 1432, c. 15, p. 510-511. 
dina del Campo en la segunda mitad de septiembre de $1431^{97}$. A pesar de que la campaña contra Granada podía presentarse como un éxito, la petición de nuevos recursos para las operaciones del año siguiente se enfrentó a una dura resistencia de los procuradores.

Se logró el otorgamiento de 45 millones de maravedís, en quince monedas y pedido y medio, a pagar en los cuatro primeros meses del año siguiente, pero hubo que dar garantías de que esas cantidades se emplearían efectivamente en la guerra contra los moros, a cuyo efecto lo recaudado sería depositado en manos de Roberto de Moya, abad de Santa María la Mayor de Valladolid ${ }^{98}$, que lo custodiaría en su fortaleza de Olivares de Duero, y de Pedro de Luzón, maestresala del rey, que tenía el alcázar de Madrid ${ }^{99}$.

También fue preciso admitir, en noviembre, el nombramiento de una comisión para supervisar el volumen y distribución de las rentas del reino ${ }^{100}$; tal designación podría responder al deseo de las Cortes de controlar el empleo de los recursos disponibles, aunque, si se considera la nómina de miembros de esta comisión, todos ello integrantes de la oligarquía que ejerce el poder, resulta difícil entender en qué forma puede hacerse efectivo aquél propósito. Hay que tener en cuenta, además, que, dos meses y medio después de su designación, serán detenidos, como se ha dicho, dos de los más importantes miembros de la misma, Pedro Fernández de Velasco, conde de Haro y don Gutierre Gómez de Toledo, obispo de Palencia, junto con miembros de su familia y casa. Acaso, además de lo argumentado contra ellos, influye en su detención una cierta oposición al condestable, quizá manifestada en las actuaciones de esta comisión.

Sin duda, la obtención del mejor rendimiento posible de los impuestos, preocupación de todas las Cortes, motivó el acuerdo de arrendar por tres años las

\footnotetext{
97 Juan II llega a Medina del Campo el día 19 de septiembre. Noticias sobre la convocatoria y el viaje del rey para su celebración, en Crónica, 1431, c. 22, p. 500; Halconero, c. 99-100; Refundición, c. 67-68.

98 Para valorar adecuadamente quien ejerce control sobre las cantidades otorgadas, conviene tener en cuenta que Roberto de Moya es una hechura de Álvaro de Luna; doctor en decretos y referendario del papa, su etapa como abad presencia importantes avances en la reforma conventual en Valladolid: instalación de los Jerónimos en Santa María de Prado, fundación del convento agustino reformado en las proximidades de Villanubla, y adscripción a la observancia del convento de san Francisco; también apoyó al reformado monasterio de san Benito de Valladolid. RUCQUOI, A. «Ciudad e Iglesia: la colegiata de Valladolid en la Edad Media», En la España Medieval, V, 1986, p. 961-984. Vid. p. 982.

99 Miembro de una familia de hidalgos que desempeñó cargos en la administración municipal de Madrid a lo largo del siglo XV. Seguramente, es hombre que cuenta con la confianza de Álvaro de Luna, que también ocupara este cargo algunos años atrás. ORTEGA CERVIGÓN, J. I. «Prestigio político y oficios reales: la nobleza conquense bajomedieval en el entorno cortesano", Anuario de Estudios Medievales, 37, 2, 2007, p. 563-595. Vid. p. 580.

100 La integran Gutierre Gómez de Toledo, obispo de Palencia; Pedro de Estúñiga, conde de Ledesma; García Fernández Manrique, conde de Castañeda; Rodrigo Alfonso Pimentel, conde de Benavente; Pedro de Velasco, conde de Haro; Pedro Manrique, adelantado mayor de León; y los doctores Pedro Yáñez y Diego Rodríguez de Valladolid. Halconero, c. 106; Refundición, c. 69.

Un cierto precedente de control sobre el empleo de los recursos puede verse en las Cortes de Segovia de 1386, en un momento de graves dificultades para el reino de Castilla, después reclamado como un derecho por las cortes de Briviesca de 1387. SUÁREZ FERNÁNDEZ, L. Juan I, p. 254 y 279.
} 
alcabalas y tercias de los años 1432-1434; de hecho se obtuvieron cinco cuentos más de lo habitualmente recaudado cuando el arrendamiento se hacía por anualidades ${ }^{101}$.

El largo cuaderno de las Cortes de Zamora ${ }^{102}$ nos transmite la sensación de que está creándose un nuevo orden institucional, propio de una nueva situación, en la que las ciudades aspiran a ejercer un papel relevante, proteger sus privilegios y lograr que sean efectivas las respuestas contenidas en los cuadernos; en cierto sentido, sus peticiones nos recuerdan la sensación de reforma propio de las Cortes de Briviesca de 1387, o dentro del propio reinado de Juan II, las de Palenzuela de 1425, que habían intentado sosegar la agitación provocada por el golpe dado por el infante Enrique y atenuar sus consecuencias posteriores.

Para una mejor comprensión de las numerosas y muy diversas peticiones de estas Cortes, de excepcional importancia, las he agrupado en seis capítulos, aunque es posible realizar diferentes clasificaciones, ya que una misma petición es susceptible de ser incluida en varios apartados: administración central y organización jurisdiccional, administración local, reparaciones e indemnizaciones, asuntos fiscales, privilegios ciudadanos, y corrección de abusos y represión de la corrupción. En todos ellos, con especial incidencia en los cuatro últimos, se recoge la advertencia de que se trata de una petición ya realizada y aceptada anteriormente, pero que no se ha llevado a efecto; no es privativo de estas Cortes que se replanteen peticiones incumplidas, pero sí la insistencia en manifestar su incumplimiento y procurar la definitiva solución.

\section{Administración central y organización jurisdiccional.}

Se plantea, en primer lugar, el adecuado ordenamiento de la Chancillería, la prestación de sus servicios por oidores, alcaldes y notarios, en el turno correspondiente, y el lugar de residencia de la Audiencia, todo lo cual había sido oportunamente dispuesto ${ }^{103}$, pero incumplido en su mayor parte, por lo que ahora se pide

101 Crónica, 1431, c. 28, p. 502.

102 Denominamos a cada una de las Cortes por el lugar y año en que se dató su Cuaderno; creo que es una innecesaria complicación hablar de Ayuntamientos y Cortes, como lo es fragmentar en diversas cortes o ayuntamientos lo que no son sino diferentes sesiones de unas mismas Cortes, celebradas habitualmente en diferentes lugares. Es el caso de estas de Medina del Campo, en 1431, y Zamora en 1432: se trata de una única reunión de Cortes, con diversas sesiones.

103 Las Cortes de Madrid de 1419, reunidas en el momento de la toma del poder por el monarca, se habían ocupado de esta cuestión en la petición primera. Se había dispuesto entonces la permanencia de un prelado y cuatro oidores por turnos de seis meses y la privación de libramiento en caso de incumplimiento de ausencia injustificada. Cortes, III, f. 11-13. B.N.E. MSS/1220, f. 4r-5v; 10628, f. 213v-217v; 10649, f. 117v-121r; 11127, f. 209r-213v; 11533, f. 481v-483r; 13104, f. 18v-20v, y 13259 , f. 15v-17r. En respuesta a la petición tercera de estas mismas Cortes se había dispuesto que la Audiencia estuviera continuadamente en Segovia, aunque por ahora, debido a la gran carestía, ha ordenado su estancia temporal en Valladolid. Cortes, III, f. 13-14. B.N.E. en los mismos manuscritos, f. $6 \mathrm{r}$; f. 218v-219v; 122v-133r; 215r-215v; 483v-484r, 21r-21v, y 17v, respectivamente. 
su ejecución y que no le sean libradas las cantidades correspondientes a su oficio a aquellos que no cumplieren la ordenanza. A pesar de lo aparentemente sencillo que habría sido ordenar la aplicación de las decisiones adoptadas, solo se obtiene la promesa de estudiar el informe emitido por una comisión designada al efecto y proveer de modo oportuno, con la excusa de que no se había podido tratar a fondo el asunto por la partida del rey de Medina del Campo ${ }^{104}$.

Los procuradores pretendieron incrementar su peso en el gobierno del reino, apelando a precedentes de época de Enrique II y Juan I ${ }^{105}$. Solicitaron que formasen parte del Consejo dos procuradores, elegidos por los que se reuniesen en cada convocatoria, con duración de su cargo hasta la siguiente reunión de Cortes y pagados con cargo a la tesorería regia ${ }^{106}$.

En el mismo sentido de incremento del protagonismo de las Cortes en el gobierno del reino debe interpretarse la petición de que las respuestas dadas a las peticiones de las Cortes tengan fuerza de ley y, a ese efecto, se redacten los documentos oportunos, que obtuvo respuesta favorable como era imprescindible ${ }^{107}$. Con cierta frecuencia las Cortes han solicitado que determinada respuesta a una de sus peticiones tenga vigor de ley, incluso que el íntegro contenido del cuaderno

\footnotetext{
Las Cortes de Palenzuela de 1425, petición primera, señalan el incumplimiento de lo establecido en las peticiones anteriores. En su respuesta, dispone el rey las personas que, por turnos de seis meses, ocuparán los cargos de oidores y alcaldes, las obligaciones de estos oficiales, y la posible designación de lugartenientes. Se fija ahora como lugares de residencia de Audiencia y Chancillería, por turno de seis meses, Turégano y Griñón o Cubas, aquende y allende los puertos, respectivamente. Cortes, III, f. 51-52. B.N.E. MSS/23, f. 193r-193v; 1220, f. 36v-38r; 10628, f. 300v-303r; 10649, f. 212r-214v; 11128, f. 43r-50v; 11533, f. 493v-494v; 13104, f. 138r-140r, y 13259, f. 38v-39r.

Finalmente, en las Cortes de Burgos de 1430, petición undécima, se designó al obispo de Palencia, Gutierre Gómez de Toledo, como presidente de la Audiencia y que, en su ausencia, ejerza las funciones el obispo de Ávila, Diego Gómez de Fuensalida. En cuanto al turno de permanencia de oidores, petición duodécima, se ordena el cumplimiento de lo acostumbrado.

104 Cortes, III, f. 117. B.N.E. MSS/23, f. 210r-210v; 1220, f. 116v-117v; 10649, f. 384v-385v; 11128, f. $186 r-187 v ; 13105$, f. $67 v-68 v$ y f. $114 v-115 v$, y 13259 , f. $75 r-75 v$.

105 En las Cortes de Valladolid de 1385, en medio de las terribles circunstancias del momento, Juan I diseñó un Consejo integrado por cuatro ciudadanos, número igual que el de prelados y caballeros, atendiendo a la petición de las Cortes que invocaron precedentes de época de Alfonso XI. No obstante advirtió rotundamente que no se trataba de una representación estamental o territorial, sino de una decisión coyuntural. De todas formas, en las Cortes de Briviesca de 1387 los cuatro procuradores fueron sustituidos por cuatro doctores. SUÁREZ FERNÁNDEZ, L. Juan I, p. 228-229 y 337-338.

106 No puede sorprendernos que la petición quinta de las Cortes recibiese una rotunda negativa, argumentando el monarca que las ciudades contaban con personas en el Consejo que les informaban adecuadamente de los asuntos de su interés y que a la réplica se respondiese tajantemente que el asunto estaba suficientemente respondido y provisto. Cortes, III, p. 120-121. B.N.E. MSS/23, f. 211 r-211v 1220, f. 119v-120v; 10469, f. 389v-390v; 11128, f. 191v-192v; 13105, f. 70v-71v, y 13259, f. 76v-77r.

107 Petición quincuagésimo segunda. Cortes, III, f. 156. B.N.E. MSS/1220, f. 154v; 6720, f. 54r; 10649, f. 444v-445r; 11128, f. 249r-249v; 13105, f. 100v-101r, y 13259, f. 92r-92v. Esta petición viene a ser el colofón del cuaderno y resumen de las aspiraciones de las Cortes; aunque el cuaderno consta de cincuenta y cinco peticiones, en realidad ésta es la última puesto que las tres restantes tienen el carácter de réplica relativa a peticiones anteriores. Alguno de los manuscritos que las contienen destaca ese carácter, incluso las recoge sin otorgarles número propio. Es el caso de B.N.E. MSS/6720, f. 54r; el MSS/1220, f. 155r-159r agrupa las tres últimas peticiones publicadas por la R.A.H. como «réplicas que hicieron los procuradores a ciertas peticiones de las antecedentes y a la ordenanza».
} 
lo tenga, como ya sucediera en las de Palencia del año anterior ${ }^{108}$. Completa el proyecto de dotar de carácter normativo a los Cuadernos de Cortes la petición de que tengan efecto aquéllas que han sido presentadas desde 1425, que obtuvieron respuesta favorable, y que, pese a ello, no se han llevado a cabo ${ }^{109}$.

Tres cuestiones sobre los excesos de la jurisdicción eclesiástica preocupan a las Cortes. Las que se derivan del abuso cometido por personas que, viviendo como laicos, pretenden excusarse de la jurisdicción civil alegando que son clérigos de corona, hecho que se agrava por tratarse frecuentemente de malhechores y delincuentes ${ }^{110}$. Este problema se había llevado a las Cortes por primera vez en las de Valladolid de 1420 a lo que el rey había respondido prometiendo escribir al Papa sobre el asunto ${ }^{111}$; de nuevo se planteó en las de Palenzuela de 1425: en esta ocasión los procuradores reclaman la celebración de una reunión de los prelados del reino para deliberar sobre el asunto pues han sabido que el Santo Padre está dispuesto a aprobar el procedimiento que éstos establezcan al respecto ${ }^{112}$.

En segundo lugar, las extralimitaciones de prelados y clérigos que dificultan la aplicación de la justicia civil, pretenden intervenir en asuntos que no pertenecen al fuero eclesiástico y fatigan a súbditos y naturales con diversas maniobras legales, en particular la citación de las partes en las cabeceras de obispado u otras ciudades de las diócesis alejadas del lugar de residencia ${ }^{113}$. Es asunto sobre el que también se habían reclamado soluciones en anteriores Cortes, sin alcanzar resultados satisfactorios ${ }^{114}$.

108 Vigor de ley solicitaron las Cortes de Burgos de 1430 para sus peticiones primera, sexta, decimotercera, decimoséptima y vigésimo octava; con carácter general, la petición décimo octava de las de Palencia de 1431.

109 Petición vigésimo séptima. Cortes, III, f. 139. B.N.E. MSS/23, f. 217v-218r; 1220, f. 138v-139r; 6720 , f. 47v; 10649, f. 416v-417r; 11128, f. 221v-222r; 13105, f. 86v, y 13259, f. 84v.

110 Además, la utilización de la excomunión y entredicho impide actuar a la justicia ordinaria. Sobre este asunto, ya tratado en Cortes, el rey había prometido escribir al Pontífice y, ahora, se decía que se había recibido bula, aunque nadie la había visto. Responde el rey que, en efecto, se ha recibido una bula de la que se dará traslado a quien lo solicite. Petición séptima. Cortes, f. 122. B.N.E. MSS/23, f. 211v; 1220, f. 121v-122r; 10649, f. 391v-392v; 11128, f. 194r-195r; 13105, f. 72r-72v, y 13259, f. 77r-77v.

111 Petición cuarta, hecha en términos idénticos a los de 1432. Cortes, III, f. 33. B.N.E. MSS/1220, f. 15r-15v; 10628, f. 254r-254v; 10649, f. 146v-147r; 11128, f. 7r-7v; 13104, f. 65v-66r; 11533, f. 467r, y 13259, f. $27 v$.

112 En esta ocasión invocan una petición al respecto del año 1422; se supone que debería hallarse en el cuaderno de las de Ocaña de ese año, pero no hemos podido hallarla. Respecto a la reunión aludida, se quejan de que no se haya celebrado y consideran que éste es el momento adecuado pues se hallan en la Corte la mayor parte de los prelados del reino. Petición duodécima. Cortes, f. 57-58. B.N.E. MSS/23, f. 195v-196r; 1220, f. 43r-44r; 10628, f. 310v-312r; 10649, f. 222r-223r; 11128, f. 59r-60v; 11533, f. 498r-498v; 13104, f. 144r-145r, y 13259, f. 40v-41r.

113 Piden para quien acuda a la jurisdicción eclesiástica, sin ser competente, privación de oficio, si lo tuviere, y una sanción de 10.000 maravedís, y denuncian las referidas maniobras legales. Responde el monarca ordenando se guarde la ordenanza, al parecer, redactada al respecto. Petición décima. Cortes, f. 124-125. B.N.E. MSS/23, f. 212v; 1220, f. 124r-125r; 6720, f. 42v-43r; 10649, f. 395v-397r; 11128, f. $198 \mathrm{v}-200$ r; 13105 , f. $74 \mathrm{v}-75 \mathrm{r}$, y 13259 , f. $78 \mathrm{r}-78 \mathrm{v}$.

114 En las Cortes de Palenzuela de 1425, petición décimo octava, ya se había establecido una sanción de 10.000 maravedís para todo laico que lleve a otro ante un tribunal eclesiástico en materias que no correspondan a esta jurisdicción. Cortes, III, f. 64. B.N.E. MSS/23, f. 198r-198v; 1019, f. 13v; 1220, 
La tercera se refiere al nombramiento de jueces conservadores no solo para personas e instituciones eclesiásticas, sino para particulares, y no únicamente en los casos previstos en derecho, sino en otros muchos, con objeto de que las citaciones ante jueces alejados impidan a la parte más débil una adecuada defensa de sus derechos ${ }^{115}$, todo lo cual constituye grave quebranto tanto para la jurisdicción ordinaria como para la eclesiástica. Algo similar ocurre también en la jurisdicción civil, en la que algunas personas relevantes logran el nombramiento de jueces alejados, lo que dificulta y encarece la acción de sus oponentes, además de contravenir los privilegios de ciudades y villas, por lo que se pide que no se realicen nuevos nombramientos y se revoquen los ya realizados ${ }^{116}$.

\section{Administración local.}

La primera preocupación en este capítulo parece ser el incremento en el número de alcaldes y regidores, clara muestra del propósito de una cerrada oligarquía de mantener su control en el gobierno de las ciudades, impidiendo el acceso de personas impuestas desde fuera, y, como veremos, cerrarlo aún más excluyendo a diversos grupos de su ejercicio. También el temor a la irrupción de la nobleza en el gobierno de las ciudades, en ocasiones contando con el concurso de una parte de esa oligarquía. El proceso se había iniciado antes del reinado de Juan II, pero había sido objeto ya de la preocupación de las Cortes en varias sesiones del mismo ${ }^{117}$; a pesar de ello, por favores otorgados por el propio rey, no se guardaban

f. 51r-51v; 6370, f. 81v-82r; 6720, f. 25r-25v; 10628, f. 321v-322v; 10649, f. 232v-233r; 11128, f. 72r-73r; 11533, f. 503-503v; 13104, f. 150v-151r, y 13259, f. 43v.

Las Cortes de Burgos de 1430 vuelven sobre esta cuestión y denuncian las maniobras de los jueces eclesiásticos que demandan en primera instancia en las cabeceras de obispados, en lugar de hacerlo en las de arcedianatos y arciprestazgos, incrementando con ello los gastos de los demandados, y toman prendas sin concurso de la justicia secular. Petición trigésimo octava. Cortes, III, f. 95-96. B.N.E. MSS/ 1019, f. 22r-22v; 1220, f. 90r-91r; 10649, f. 324v-326r; 11128, f. 139v-141r; 13104, f. 201v-202v 13105 , f. $20 \mathrm{v}-21 \mathrm{v}$, y 13259 , f. 61 r. A pesar de haber escrito sobre ello a los prelados, no ha tenido el oportuno efecto, por lo que reclaman les dirija nuevas misivas. Petición trigésimo novena. Cortes, III, f. 96-97. B.N.E. MSS/1220, f. 91r-91v; 6720, f. 32v; 1019, f. 22v; 10649, f. 326r-326v; 11128, f. 141r-142r; 13105 , f. 21v-22r, y 13259, f. 61r-61v.

${ }^{115}$ Entienden los procuradores que todos los que viven en el reino deben contentarse con la jurisdicción ordinaria y no pretender presionar a otros con la utilización de maniobras de este tipo. Por ello requieren que ordene a sus súbditos que no utilicen las conservadurías ya otorgadas ni soliciten otras nuevas, y que pida al Papa que revoque las actuales conservadurías y no otorgue otras nuevas. Petición trigésimo quinta. Cortes, f. 145. B.N.E. MSS/1220, f. 144r-144v; 10649, f. 424r-425r; 11128, f. 230r-232r; 13105, f. 91v-92r, y 13259, f. 86v-87r.

${ }_{116}$ La respuesta real es positiva en lo referente a no realizar nuevos nombramientos; en cuanto a los ya nombrados pide relación nominal y promete decidir sobre ello. Petición cuadragésimo sexta. Cortes III, f. 152-153. B.N.E. MSS/1019, f. 39r; 1220, f. 151v-152r; 10649, f. 435v-436v; 11128, f. 244r-244v; 13105, f. $98 \mathrm{r}-98 \mathrm{v}$, y 13259 , f. $90 \mathrm{v}$.

117 Se plantea por primera vez en la petición octava de las Cortes de Madrid de 1419, que tienen carácter de inauguración del reinado, invocando ordenanzas antiguas. Cortes, III, f. 16; B.N.E. MSS/1019, f. 2r; 1220, f. 7r-7v; 6720, f. 15r-15v; 10628, f. 223r-223v; 10649, f. 126v-127r; 11127, f. 219v-220r; 11533, f. 485v; 13104, f. 23r, y 13259, f. 19r; de nuevo se plantea esta cuestión, unida a otras como la reserva de los cargos concejiles a los naturales y vecinos y moradores con diez años de antigüedad, en las de Valladolid 
aquellas disposiciones. Por ello piden que, en el momento en que vaquen, se amorticen todas las alcaldías, regimientos y escribanías que exceden el número acostumbrado; que en adelante no se incremente dicho número sino a petición de la propia ciudad, y que se sancione con privación del oficio a aquellos oficiales urbanos que pretendan nombrar a otro en las vacantes que hayan de ser amortizadas $^{118}$.

Las dificultades y presiones a que se enfrentan alcaldes y regidores en el gobierno de la ciudad muestran claramente la irrupción de caballeros y escuderos en la vida urbana. Por ello, ya habían pedido ${ }^{119}$, y piden de nuevo, que no se hallen en los ayuntamientos otras personas que las previstas, que solo alcaldes y regidores intervengan en el gobierno de la ciudad, que se respeten las ordenanzas en aquellas ciudades en que las hay, que se actúe de modo similar en aquéllas que carecen de ellas, y que las quejas contra sus actuaciones tengan el curso previsto en derecho ${ }^{120}$. Para reforzar a alcaldes y alguaciles, dispone el monarca que todos los regidores y oficiales de ciudades y villas estén obligados a prestarles ayuda para la ejecución de la justicia cuando hayan de intervenir en escándalos promovidos por poderosos o suscitados entre ellos ${ }^{121}$.

El nombramiento de corregidores es un procedimiento habitual para resolver los problemas planteados por la mala administración de un concejo o la existencia de problemas que requieren una intervención directa del poder real. Sin embargo,

de 1420, petición primera, a la que se responde ordenando que se cumpla lo dispuesto, aunque se den cartas en contrario con cláusulas derogatorias. Cortes, III, f. 30-32. B.N.E. MSS/1019, f. 4r-5r; 1220, f. 12r-13v; 6720, f. 17r-18r; 10628, f. 249v-252r; 10649, f. 143r-145r; 11128, f. 1v-4v; 13104, f. 62v-64r; 11533, f. 465r-466r, y 13259 , f. 26v-27r, y en las de Palenzuela de 1425, petición tercera, que reitera la anterior respuesta. Cortes, III, f. 53. B.N.E. MSS/23, f. 194r; 1019, f. 10v-11r; 1220, f. 38r-38v; 6720, f. 22r; 10628, f. 303v-304v; 10649, f. 215r-215v; 11128, f. 51r-52r; 11533, f. 494v-495r; 13104, f. 140r-140v, y 13259, f. 39r-39v.

118 Petición segunda. Cortes, III, f. 118-119. B.N.E. MSS/23, f. 210v; 1019, f. 26r-26v; 1220, f. 117v-118v; 6720, f. 40v-41r; 10649, f. 385v-387v; 11128, f. 187v-189v; 13105, f. 68v-69v y 115v-116r, y 13259, f. 75v-76r.

119 Las Cortes de Palenzuela de 1425, petición décimo cuarta, habían manifestado las severas amenazas (derribo de casas) que personas poderosas ejercen sobre alcaldes y regidores y que incluso organizan gobiernos paralelos sin participación de aquéllos. Cortes, III, f. 60-61. B.N.E. MSS/23, f. 196v-197r; 1019, f. 11v-12v; 1220, f. 46r-48v; 6720, f. 23r-24r; 10628, f. 315r-318r; 10649, f. 226r-229r; 11128, f. 64v-68r; 11533, f. 500r-501v; 13104, f. 146v-148v, y 13259, f. 41v-42. También las Cortes de Ocaña de 1422, petición décimo sexta, habían denunciado los levantamientos promovidos por estas personas contra las decisiones del regimiento y solicitado que se guarden las ordenanzas y se impongan adecuados castigos a los promotores a aquellos alborotos. Cortes, III, f. 45. B.N.E. MSS/1019, f. $5 v-6 r ; 1220$, f. 28v-29v; 6720, f. 21r-21v; 10628, f. 274v-276r; 10649, f. 179v-181r; 11128, f. 33v-35v; 11533, f. 477r-477v; 13104, f. 90r-91r, y 13259, f. 32v-33r.

En ese mismo sentido, las Cortes de Madrid de 1419, petición décima, reclaman la expulsión de las ciudades de rufianes y vagabundos que, protegidos por personas poderosas, causan severos problemas sin que alcaldes y regidores puedan proceder contra ellos. Cortes, III, f. 16-17. B.N.E. MSS/1019, f. $2 v ; 1220$, f. 7v; 6720, f. 15v-16r; 10628, f. 223v-224r; 10649, f. 127r-127v; 11127, f. 220v-221v; 11533, f. 485v-486r; 13104, f. 23v, y 13259, f. 19r-19v.

120 Petición octava. Cortes, III, f. 122-123. B.N.E. MSS/23, f. 212r; 1019, f. 26v-27v; 1220, f. 122r-123r; 6720, f. 41v-42r; 10649, f. 392v-394r; 11128, f. 195r-197r; 13105, f. 72v-73v, y 13259, f. 77v-78r. La respuesta real dispone que en los ayuntamientos entre únicamente justicias y regidores y, en su caso los sexmeros, de acuerdo con la ordenanza prevista.

121 Petición quincuagésima. Cortes, III, f. 154-155. B.N.E. MSS/1220, f. 153v-154r; 6720, f. 53v; 10649, f. 438v-439r; 11128, f. 247r-248r; 13105, f. 99v-100r, y 13259, f. 91v-92r. 
la designación de corregidores no está exenta, a su vez, de problemas: que se reclame su nombramiento por una determinada facción, empleando testigos ganados a su opinión ${ }^{122}$; que no desempeñen adecuadamente su misión, alarguen el tiempo de su corregimiento, pongan oficiales en su nombre, creen mas divisiones que soluciones a los problemas de la ciudad, se preocupen solo de sus intereses, o que adquieran tanto poder que los vecinos carezcan de medios para querellarse por los agravios recibidos ${ }^{123}$.

Por ello habían solicitado que solo se designen corregidores cuando fuese preciso, de acuerdo con información fiable; que cada cierto tiempo fuesen enviados pesquisidores a las ciudades para comprobar cómo ejerce sus funciones el corregidor, y que su mandato durase un tiempo determinado, porque las ciudades, además de ver quebrantados sus privilegios y libertades, han de pagar sus salarios y sufrir muchos excesos realizados en nombre de la justicia ${ }^{124}$.

Aunque el rey había respondido afirmativamente a estas peticiones, y limitado a dos años el mandato de los corregidores, lo cierto es que aquellos excesos no se han corregido. Lo que se pide ahora constituye una revisión total del sistema de corregimientos que, de haber triunfado la petición, habría supuesto su abandono: que se revoquen todos los nombramientos vigentes en el momento y que, en el futuro, se cite a la corte a los caballeros y poderosos responsables de los bullicios

122 Este problema ya había sido planteado en las Cortes de Palenzuela de 1425, petición trigésima. Así se lograba el envío de corregidor y el resultado, en gráfica explicación de los procuradores, es que «muchos de los corregidores trabajan para reunir dinero y hacer su provecho y se preocupan poco de la justicia, y si mal estaba el pueblo cuando iban, peor quedaba cuando partían». Por eso se había pedido que se reciba información de personas dignas de crédito, no partidistas, si es preciso mediante envío de persona fidedigna, cuyo informe decida si se envía o no corregidor. La respuesta fue positiva. Cortes, f. 69-70. B.N.E. MSS/23, f. 200v-201r; 1220, f. 57v-58v; 6720, f. 27v-28r; 10628, f. 330v-332r; 10649 , f. $241 v-242 v ; 11128$, f. $843-85 v$; 13104, f. $156 v-157 v$, y 13259, f. 46 r.

${ }^{123}$ Estos problemas fueron planteados en la petición trigésima de las Cortes de Burgos de 1430, en la que se pidió el envío de pesquisidores para conocer el modo de ejercer su misión. En la respuesta rea se establece la duración máxima de dos años para el corregimiento, que se reducirá a sólo uno en las de Zamora de 1432. Cortes, III, f. 92. B.N.E. MSS/1220, f. 86r-86v; 6720, f. 31r-31v; 10649, f. 318v-319v; 11128, f. 132r-132v; 11533, f. 521r-521v; 13104, f. 199v-200r; 13105, f. 17r-17v, y 13259, f. 59v.

124 En las Cortes de Ocaña de 1422 se presentaron tres peticiones sobre los corregidores, que recogen los problemas que presenta su gestión. Se quejan las Cortes, petición segunda, de que la designación de corregidores, sin petición de la mayoría de los vecinos, supone tres agravios: quebrantamiento de la ley del ordenamiento que exige esta condición; quebrantamiento de los usos y costumbres de las ciudades que tienen atribuida la justicia civil y criminal; incremento de disensiones. Si se envía corregidor sin petición de la ciudad, sea a cargo del erario real y, después, cobrado a los culpables. La respuesta ordena que sea observada la Ordenanza dispuesta al respecto por Enrique III. Cortes, III, f. 37. B.N.E. MSS/1220, f. 18v-19v; 6720, f. 18v-19v; 10628, f. 259v-261r; 10649, f. 165v-167r 11128, f. 15v-17v; 11533, f. 470v-471r, y 13259, f. 29r.

La tercera petición de estas Cortes solicita que no sea designado corregidor el pesquisidor que informó acerca de la necesidad de envío de aquél oficial. Cortes, III, f. 37-38. B.N.E. MSS/lbid. f. 19v-20r; f. 19v; 261r-261v; 167r-167v; 17v-18r; 471r-471v; 80r-80v, y 29r-29v, respectivamente.

Para desempeñar el cargo de corregidor considera la petición cuarta de estas Cortes que es precisa alguien idóneo, llano, no poderoso, que sirva el oficio por sí mismo. De acuerdo con la respuesta regia, así se hará tanto en los corregimientos actuales como en los futuros. Cortes, III, f. 38. B.N.E. MSS/1220, f. 20r-20v; 10628, f. 261v-262v; 10649, f. 167v-168r; 11128, f. 18r-19r; 11533, f. 471v; 13104, f. 80v-81r, y 13259 , f. $29 \mathrm{v}$. 
ciudadanos y a los alcaldes y regidores que no cumplen sus obligaciones y se les imponga el castigo oportuno. Con ello se castigaría a los culpables y no, como ahora, a los simples pecheros ${ }^{125}$.

La respuesta real no suprime el sistema de corregimiento, pero introduce sustanciales modificaciones en el nombramiento, objeto del mandato, retribuciones y duración, que deberían producir una renovación completa del mismo, así como una serie de medidas transitorias para resolver la situación actual sin llegar a una revocación general. El nombramiento de corregidor solo se hará a petición de la mayoría del regimiento, no en respuesta a otras informaciones sin contrastarlas con la propia ciudad. Serán las justicias de cada ciudad quienes habrán de notificar los conflictos, y los corregidores o pesquisidores nombrados tendrán jurisdicción exclusivamente sobre estos asuntos, no general, y sobre ellos será temporalmente incompetente la justicia local. Su salario, correrá a cargo de las partes afectadas o de la justicia cuya negligencia ha hecho preciso el nombramiento de estos oficiales especiales.

En cuanto a la duración se establece un límite máximo de un año, al cabo del cual el corregidor habrá de dar cuenta de su cometido ${ }^{126}$ y, si no lo hiciese, estará obligado a devolver el salario recibido. Respecto a los actuales corregidores se dispone que pueda desempeñarlo cuatro meses más quien lo ha ejercido durante un año, con objeto de concluir su misión, con advertencia de que, de no hacerlo, habrá de devolver todo el salario recibido; en caso de que la ciudad solicite que se mantenga el corregimiento, se nombrará nuevo corregidor. Quienes no han alcanzado el año, lo desempeñarán, asimismo durante cuatro meses, con idénticas condiciones; los que han superado dos años cesarán de modo inmediato. En todo caso el oficio deberá ser servido personalmente, no por sustitutos.

Para el correcto funcionamiento de las instituciones urbanas, parece oportuno a los procuradores que se establezca la obligatoriedad de que los jurados residan en las parroquias de las que lo son, o en un término que se señale ${ }^{127}$. Precisamente, sobre la administración ciudadana se han aprobado algunas ordenanzas, no a petición de las Cortes, sino a iniciativa regia, que han establecido que una persona solo pueda tener un oficio de regimiento y que el regidor solo cobre salario si efectivamente está ocupado en su desempeño, así como la inexcusable obligación

125 Petición undécima. Cortes, III, f. 125-128. B.N.E. MSS/23, f. 212v-213v; 1019, f. 28r-29v; 1220, f. 125r-128r; 6720, f. 43r-45r; 10649, f. 397r-401r; 11128, f. 200r-204v; 13105, f. 75r-77v, y 13259, f. 78v-80r.

${ }_{126}$ En las Cortes de Madrid de 1419, petición sexta, se había recordado que los corregidores no cumplen la obligación establecida de cincuenta días de residencia al final de su mandato. Por ello piden los procuradores que se cumpla efectivamente esa disposición, que las justicias de la ciudad se lo impongan, les tomen fiadores o, si no los dan, los envíen presos a su costa a las ciudades donde ejercieron su cargo, todo ello en el plazo de un año de finalizado su cometido. Se ordena el cumplimiento de las leyes relativas a esta cuestión. Cortes, III, f. 15. B.N.E. MSS/1019, f. 1v-2r; 1220, f. 6v-7r; 10628 f. 221r-222v; 10649, f. 124v-126r; 11127, f. 217v-219r; 11533, f. 484v-485r; 13104, f. 22r-23r, y 13259, f. 18v.

127 Caso de no cumplir esta norma podrán ser sustituidos. Petición cuadragésimo séptima. Cortes, III, f. 153. B.N.E. MSS/1019, f. 39r-39v; 1220, f. 152r-152v; 10649, f. 436v-437r; 11128, f. 244v-245r; 13105 f. $98 \mathrm{v}$, y 13259 , f. $91 \mathrm{r}$. 
de todos los vasallos que tienen tierra del rey de acudir a la convocatoria a las armas, sin poder excusarse por desempeño de oficio, so pena de pérdida del beneficio y confiscación de bienes, además de las penas previstas en la ley ${ }^{128}$.

Estas ordenanzas provocaron una fuerte resistencia; de hecho, por el momento, solo conocemos su existencia por la referencia a ellas en una petición a modo de réplica al final del cuaderno solicitando su suspensión; se alega que algunas personas tienen naturaleza en más de un lugar, con casa poblada, lo que les permite aspirar a oficios en ellos, que muchos Grandes y miembros del Consejo tienen diferentes oficios, raciones por ellos y grandes quitaciones, y que supondría gran perjuicio para quienes desempeñan un oficio de regimiento, con un salario de mil o dos mil maravedís, no poder atender adecuadamente sus haciendas. Por ello piden que, en todo caso, se disponga así para el futuro y que no se incluya en las respuestas porque provocaría escándalos similares a la ordenanza sobre los vasallos, asunto éste que fue objeto de prolongadas discusiones ${ }^{129}$.

La respuesta real, bastante contundente, niega la derogación de esta norma, aunque con el importante matiz de su aplicación solo a partir de este momento, sin afectar a la situación actual; dispone, en consecuencia, que en las cartas de provisión de un oficio de regimiento se incluya la cláusula de nulidad, si el número excede al establecido, o si el nombrado tiene ya otro regimiento, y que referendarios, secretarios, escribanos y cancilleres no pasen estos nombramientos, que en todo caso serán nulos, si omiten estas cláusulas.

Otra de estas réplicas finales solicita la supresión en las respuestas de la ordenanza que obliga a todos los vasallos a servir personalmente al rey sin excusa por el desempeño de un oficio; se trata, aseguran, de una iniciativa regia, a pesar de lo cual, en las cartas de apercibimiento libradas por los contadores mayores, se dice que se trata de una petición de los procuradores, afirmación que suponen podrá crear conflictos entre éstos y aquéllos. Al pedir la supresión de este ordenamiento del conjunto de las respuestas, solicitan se tengan en cuenta razones de edad, enfermedad o pobreza como eximentes o causas de sustitución por otra

128 Se contiene noticia de estas ordenanzas, como si se tratase de peticiones de las Cortes, en B.N.E. MSS/1019, f. 40r, y 6720, f. 53v-54r. Texto similar, formulado como petición quincuagésimo primera en Cortes, III, f. 155-156. B.N.E. MSS/1220, f. 154r-154v; 13105, f. 100r-100v, y 13259, f. 92r. En todos ellos el texto difiere del habitual de una petición de Cortes y se asemeja más a un índice de diversas disposiciones. Además, el MSS/1220, f. 154v, en la disposición que establece que solo pueda desempeñarse un oficio de regimiento simultáneamente, incluye una nota marginal que dice "ordenanza», y en la que establece la obligación de los vasallos otra nota marginal que dice: «ley sin petición, véase adelante en las réplicas 2 y 3», que corresponden a las peticiones quincuagésimo cuarta y quincuagésimo quinta del Cuaderno publicado por la R.A.H.

129 Esta petición figura como quincuagésimo quinta del texto publicado por la R.A.H. Cortes, III, f. 158-160. Es la tercera de un grupo de tres peticiones incluidas al final del cuaderno a modo de réplicas; incluso el MSS/1220 de la B.N.E., que las incluye en los f. 155r-159r, advierte que son «réplicas que hicieron los procuradores a ciertas peticiones de las antecedentes y a la ordenanza». B.N.E. MSS/6720, f. 55r-56r; 10649, f. 447r-447v; 11128, f. 252r-255r; 13105, f. 102r-103v, y 13259, f. 93r-94r. Texto similar, con ligeras variantes, MSS/ 10649, f. 439r-441v, y en el propio 11128, f. 248r-249r. 
persona, y que, en todo caso, se revise la extrema severidad de las penas establecidas en este caso ${ }^{130}$. La respuesta real admite que la ordenanza se debe a iniciativa regia, pero afirma rotundamente que las exenciones por razones de edad, salud o desempeño de oficio están bien previstas en las leyes y se niega a cualquier revisión de las penas establecidas.

Esta intervención de las Cortes, tratando de justificar ciertos incumplimientos de las obligaciones militares por parte de los oficiales urbanos, solo pretende impedir un colapso de la administración municipal por la forzada ausencia de un importante número de ellos. Lo habían puesto claramente de manifiesto, como hemos visto, las Cortes de Burgos de 1430: la convocatoria general que ha supuesto la guerra con Aragón, si se cumpliesen estrictamente las obligaciones militares, se decía entonces, paralizaría la vida ciudadana ${ }^{131}$. De nuevo se produce otra intervención de los procuradores a favor de estos vasallos en las Cortes de Palencia del año siguiente: ante la orden de confiscación de tierras de los que no acudieron a la guerra piden se tengan en consideración las razones que puedan excusarlos legítimamente de esa obligación y que sean benignamente oídos ${ }^{132}$

También plantea algunos problemas a la administración municipal el desempeño simultáneo de oficios municipales y profesionales, como físicos, cirujanos, alfajemes y albéitares, porque les confiere, al mismo tiempo, jurisdicción y atribuciones profesionales sobre los ciudadanos que aspiran al ejercicio de cualquiera de dichas profesiones, lo que va contra los privilegios de las ciudades y de los súbditos. Por ello piden, y el rey así lo ordena, la suspensión temporal en sus oficios durante el desempeño de un cargo $^{133}$.

La determinación de la mayoría cualificada para la validez de las decisiones municipales es asunto que causa no pocos enfrentamientos y, sobre todo, obstaculiza la tramitación de los asuntos, especialmente debido a las diferencias existentes al respecto entre las diversas ordenanzas municipales, sus contradicciones internas, en ocasiones, incluso a la carencia de ordenanzas. En algunos casos se establece una mayoría de dos tercios, en otros mayoría simple y, en muchos de los que carecen de ordenanzas, algunos reclaman unanimidad.

Por ello se pide el establecimiento como norma general de una mayoría simple; responde el rey ordenando que se cumpla lo previsto en las respectivas ordenan-

130 Se refiere a la ordenanza que acabamos de citar, incluida de modo apresurado como petición de Cortes, y que, según se ha afirmado había suscitado enconada polémica; como ahora se demuestra, ésta y las otras ordenanzas respondían a iniciativa regia, hecho ratificado por la resistencia a derogarla. Petición quincuagésimo cuarta. Cortes, III, f. 157-158. B.N.E. MSS/1220, f. 155v-156v; 6720, f. 54v-55r; 10649, f. 445v-447r; 11128, f. 250v-252r; 13105, f. 101r-102r, y 13259, f. 92v-93r.

131 Petición trigésimo segunda. Cortes, III, f. 93-94. B.N.E. MSS/1220, f. 86v-88r; 10649, f. 320r-321v; 11128, f. 133v-135r; 11533, f. 521v-522v; 13105, f. 17v-18v, y 13259, f. 59v-60r.

${ }_{132}$ Petición décimo quinta. Cortes, III, f. 102-103. B.N.E. MSS/1220, f. 98v-99r; 10649, f. 339v-340r; 11128 , f. $154 \mathrm{v}-155 \mathrm{v} ; 13105$, f. $46 \mathrm{r}-46 \mathrm{v}$, y 13259, f. $68 \mathrm{r}$.

133 Petición vigésimo octava. Cortes, III, f. 139-140. B.N.E. MSS/ 23, f. 218r; 1019, f. 33v; 1220, f. 139r-139v; 10649, f. 417r-418r; 11128, f. 222r-223r; 13105, f. 86v-87r, y 13259, f. 84v-85r. 
zas o, caso de no haberlas, o ser contradictorias, que se aplique lo previsto en derecho ${ }^{134}$. Respuesta aparentemente contundente, pero con fisuras evidentes, lo que motiva la primera de las tres réplicas finales a que nos hemos referido; en efecto, las previsiones legales no son lo suficientemente concretas como para no suponer encontradas interpretaciones jurídicas, por lo que los procuradores reclaman nuevamente el establecimiento de la mayoría simple como criterio de fácil e indiscutible aplicación. Sin embargo fue contundentemente rechazado en la respuesta regia ${ }^{135}$.

\section{Reparaciones e indemnizaciones.}

Se agrupan en este apartado aquellas peticiones relativas a los daños causados por las guerras, especialmente con Aragón y Navarra, que no han sido reparados, ni indemnizados adecuadamente los damnificados, a pesar de tratarse de peticiones realizadas con anterioridad, que, además, habían recibido respuesta favorable; aunque el reproche por incumplimiento de respuestas dadas en Cortes es tónica dominante en éstas de 1432, se concentra en este capítulo esa situación, pues todas las peticiones comprendidas en él habían sido respondidas positivamente e incumplidas hasta el momento.

Se plantea en primer lugar un hecho que puede crear situaciones de peligro para el reino; se refiere al mal estado de castillos, alcázares y casas fuertes de la frontera, tanto de la de Granada como del resto de reinos. Planteado con anterioridad, se había respondido que las reparaciones se acometerían con las cantidades pagadas a partir de ahora por el rey de Granada ${ }^{136}$; a pesar de ello, las obras acometidas eran mínimas. Anticipándose a la posible respuesta de que no se disponía de aquellos fondos, porque la restauración de Yusuf fue considerada por muchos en Castilla como efímera y llena de riesgos, los procuradores piden que se disponga de otras partidas para resolver un problema extenso y de graves consecuencias. Dispone el rey que así se haga en lo referente a castillos de frontera y que sean los vecinos de cada ciudad quienes acometan a su costa la reparación de sus respectivos muros y torres ${ }^{137}$.

134 Petición cuadragésimo novena. Cortes, III, f. 154. B.N.E. MSS/1019, f. 39r-40r; 1220, f. 153r-153v; 6720, f. 53r-53v; 10649, f. 437v-438v; 11128, f. 246r-247r; 13105, f. 99r-99v, y 13259, f. 91v.

135 Petición quincuagésimo tercera. Cortes, III, f. 156. B.N.E. MSS/1220, f. 155r-155v; 6720, f. 54r-54v; 10649 , f. 445r-445v; 11128, f. 249v-250v; 13105, f. 101r, y 13259, f. 92v.

136 Se refiere a los compromisos contraídos por Yusuf ibn Al Mawl en septiembre de 1431, que le convertían en vasallo de Juan II, además de obligarle al pago de 20.000 doblas anuales, cuando fuese reconocido sultán. El acuerdo se hizo efectivo el 27 de enero de 1432, una semana después de la fecha del cuaderno de estas Cortes, cuando, al tomar posesión de Granada ratificó aquellos acuerdos. En la primeras sesiones de estas Cortes, en Medina del Campo, se trató de acometer las obras necesarias, que lo serían con aquellos fondos. Poco o nada se había hecho realidad; seis meses después terminaba violentamente el efímero reinado de Yusuf IV y Muhammad IX, que recuperaba el poder apoyado en la facción contraria a cualquier entendimiento con Castilla, suprimía todo compromiso.

137 Petición tercera. Cortes, III, f. 119. B.N.E. MSS/23, f. 210v-211r; 1220, f. 118v-119r; 10649, f. $387 v-388 v$; 11128, f. 189v-190v; 13105, f. 69v-70r y 116r-117r, y 13259, f. 76r-76v. 
Las cuatro peticiones restantes de este capítulo se refieren a la reparación de los trastornos económicos motivados por la situación de guerra. En primer lugar los daños causados por la gente de armas al servicio del propio rey, petición ya presentada en ocasiones anteriores y a la que se había respondido que se investigarían los hechos y, descontadas las correspondientes cantidades a los responsables, se indemnizaría a los damnificados ${ }^{138}$. A pesar de ello no se han pagado los daños provocados en 1425, ni los causados en los años 1429, 1430 y 1431. Asegura el rey haber dado oportuna orden de pago de todo ello ${ }^{139}$.

La guerra con el reino de Aragón y Navarra, al mismo tiempo conflicto entre reinos y enfrentamiento con los Infantes y sus partidarios en Castilla, provoca intrincados choques de intereses entre quienes han prendido algunos bienes de aquellos, en compensación por los daños que han sufrido durante la guerra, y los beneficiados por merced regia con los bienes confiscados a los «aragoneses», que pretenden hacer efectiva la posesión de la totalidad de los bienes que les han sido otorgados. Parece razonable a los procuradores que los damnificados, que han logrado por sí mismos alguna compensación por sus daños, no se vean despojados de sus presas o en todo caso sean previamente compensados de modo adecuado ${ }^{140}$. Pide el rey una relación de los que se hallan en esta situación, que serán oídos en la Corte, y promete justicia.

Concluye este apartado con dos peticiones que pretenden cerrar los perniciosos efectos económicos de la guerra, sobre las que ya se habían hecho inútiles peticiones en ocasiones anteriores; se refieren a las cantidades tomadas en diversos modos a personas y entidades para financiar el esfuerzo bélico. Una de ellas se refiere al pago o devolución de la plata tomada en préstamo de iglesias y monasterios; aunque había respondido en su momento que había dado orden a los contadores de efectuar el pago ${ }^{141}$, éste no se había producido, por lo que reiteran

138 Tienen sobrada razón los procuradores. En las Cortes de Palenzuela, petición trigésimo sexta, se demanda que se investiguen los daños de este mismo año, a lo que el rey responde que ya ha nombrado a las personas que han de investigarlo y que su importe será descontado de su sueldo a los causantes. Cortes, III, f. 74. B.N.E. MSS/23, f. 202v-203r; 1220, f. 63r-63v; 10628, f. 338r-338v 10649, f. 249r-250r; 11128, f. 93v-94r; 13104, f. 162r-162v, y 13259, f. 47v-48r. En unas Cortes tan preocupadas por las consecuencias de la guerra como las de Burgos de 1430, petición décimo cuarta, se vuelve sobre esta cuestión, insistiendo, con cierta ironía, que de nada vale investigar si no se paga, y requiriendo orden de que los contadores paguen. Cortes, III, f. 86. B.N.E. MSS/1220, f. 78r; 10649, f. 308r-308v; 11128, f. 119r-119v; 11153, f. 514v-515r; 13105, f. 9v, y 13259, f. 56v. Apenas unos meses después, en las Cortes de Palencia de 1431, petición décima, se vuelve sobre esta misma cuestión pidiendo el pago de los daños investigados, al parecer ya descontados a sus causantes, como los provocados por los aragoneses y navarros en aquellas fronteras; también en este caso con respuesta favorable, pero, ya se ve, poco efectiva una vez más. Cortes, III, f. 101; B.N.E. MSS/1220, f. 96-97r; 10649, f. 337r-337v; 11128, f. 151v-152v; 13105, f. 44r-44v, y 13259, f. 67v.

139 Petición décimo cuarta. Cortes, III, f. 130-131. B.N.E. MSS/23, f. 214v; 1220, f. 130v-131r; 10649, f. $405 r-405 v ; 11128$, f. 209r-209v; 13105, f. 79v-80r, y 13259, f. 81 r.

140 Petición cuadragésimo segunda. Cortes, III, f. 149-150. B.N.E. MSS/1220, f. 148v-149r; 10649, f. 431r-432r; 11128, f. 238v-239v; 13105, f. 95v-96r, y 13259, f. 88v-89r.

141 En las Cortes de Burgos de 1430, petición octava, se había presentado protesta por la forma en que se había efectuado la toma de plata, precipitada y perentoriamente, sin respetar objetos de culto, 
la petición. Asegura el monarca que ha pagado gran parte de aquella deuda y que da orden de que se pague de modo inmediato el resto ${ }^{142}$.

La segunda, idéntica a la anterior, se refiere a las cantidades tomadas a ciudades y villas y particulares, sobre lo que, asimismo, se había solicitado devolución y obtenido respuesta positiva, pero no efectiva ${ }^{143}$. Por eso se solicita nuevamente y se obtiene, lógicamente, respuesta afirmativa ${ }^{144}$.

\section{Asuntos fiscales.}

Las cuestiones de carácter fiscal constituyen la preocupación más importante de los procuradores en estas Cortes, por encima, incluso, de los asuntos relacionados con la administración local; quince de las cincuenta y cinco peticiones de este cuaderno se refieren a materia fiscal: pretenden la máxima eficacia en la recaudación y un adecuado reparto de las cargas que alcance a todos los obligados al pago, eliminando injustas exenciones.

La primera cuestión relativa a estos asuntos se refiere a un impuesto, denominado la "quema», establecido en Aragón, en particular en el reino de Valencia, sobre el tráfico de mercancías entre este reino y Castilla, en ambas direcciones ${ }^{145}$. Era un asunto objeto de varias peticiones de anteriores sesiones de Cortes $^{146}$, al

a lo que había respondido que se trató de préstamos voluntarios, hecho que los procuradores niegan, y, en todo caso, con promesas de solución. Cortes, III, f. 83-84. B.N.E. MSS/1220, f. 75r-76r; 10649, f. 304r-305v; 11128, f. 114v-116r; 11533, f. 512r-513r; 13105, f. 6v-7r, y 13259, f. 55v-56r. De nuevo fue planteado el asunto en las Cortes de Palencia de 1431, a lo que se respondió que se daba orden de pago a los contadores mayores, respuesta que ahora invocan los procuradores. Petición sexta. Cortes, III, f. 99-100. B.N.E. MSS/1220, f. 95r; 10649, f. 334v-335r; 11128, f. 148v-149r; 11533, f. 527r-527v; 13105, f. $43 r$, y 13259 , f. $66 v-67$ r.

142 Petición vigésimo quinta. Cortes, III, f. 138. B.N.E. MSS/23, f. 217v; 1220, f. 137v-138r; 10649, f. 415r-416r; 11128, f. 220r-221r; 13105, f. 85v-86r, y 13259, f. 84r.

${ }_{143}$ También se habían quejado los procuradores de las Cortes de Burgos de 1430, petición décima, de la violencia con que han procedido los encargados de requerir préstamos de ciudades y villas, que el rey manifiesta no haber ordenado, aunque admite que se ha producido. Cortes, III, f. 84. B.N.E. MSS/1220, f. 76r-76v; 10649, f. 305v-306r; 11128, f. 116v-117r; 11533, f. 513r-513v; 13105, f. 7v-8r, y 13259 , f. 56r. También en este caso fue preciso insistir que se diesen las órdenes oportunas para el pago. Cortes, III, f. 100. B.N.E. MSS/1220, f. 95r-95v; 10649, f. 335r-335v; 11128, f. 149r-150r; 13105 f. 43r-43v, y 13259 , f. 67 r.

144 Petición vigésimo sexta. Cortes, III, f. 138-139. B.N.E. MSS/23, f. 217v; 1220, f. 138r-138v; 10649, f. 416r-416v; 11128, f. 221r-221v; 13105, f. 86r-86v, y 13259, f. 84r-84v.

145 Sobre este impuesto, véase, DIAGO HERNANDO, M. «La "quema". Trayectoria histórica de un impuesto sobre los flujos comerciales de Castilla y Aragón (siglos XIV-XV)». Anuario de Estudios Medievales, 30/1, 2000, 91-156. («La quema»). El impuesto, cobrado a lo largo del siglo XIV, había experimentado fluctuaciones en su aplicación, con algunos periodos de suspensión y, de hecho, se había extinguido su cobro en el reino de Aragón propiamente dicho, seguramente desde los años finales del s. XIV, en opinión de este autor, p. 148.

${ }^{146}$ El asunto había sido planteado por primera vez en las Cortes de Madrid de 1419, petición décimo cuarta, entonces referido al reino de Valencia. Piden que se actúe al respecto como hizo Enrique III, que quitó dicho impuesto. La respuesta fue entonces muy vaga: solicitar al rey de Aragón que le suprima. Cortes, III, f. 18. B.N.E. MSS/1220, f. 8v; 10628, f226v-227r; 10649, f. 130r-130v; 11127, f. 224r-224v; 11533, f. 487r-487v; 13104, f. 25r-25v, y 13259, f. 20r-20v. Tiene su lógica que se plantee ahora la petición porque, 
que se había prometido rápida solución y en el que nada se había resuelto, antes bien se habían incrementado los gravámenes por éste y otros conceptos. La respuesta regia promete, una vez más, proveer sobre este asunto que, por el momento es objeto de pleito ante jueces diputados por los monarcas de ambos reinos ${ }^{147}$.

El proceso de cobro de los impuestos y el manejo de las cantidades recaudadas plantean algunos problemas que, en definitiva, repercuten en la carga fiscal y en el rendimiento de los recursos obtenidos. Las condiciones de arrendamiento tienen influencia decisiva sobre la carga fiscal; por ello habían pedido los procuradores que éstas se fijaran con su participación y que, una vez fijadas, no fueran modificadas sin su acuerdo, según costumbre, al igual que la determinación de las obligaciones a que ha de hacer frente el reino. Por el momento nada puede hacerse sobre este asunto porque las rentas del reino han sido arrendadas por espacio de tres años ${ }^{148}$

El plazo de recaudación de monedas, que llega a seis meses, produce algunos inconvenientes derivados de la modificación, durante ese tiempo, de las condiciones personales del contribuyente, que pueden hacerle sujeto a la obligación en un momento determinado, no estándolo en el momento en que se estableció dicho impuesto. La respuesta real remite a lo previsto por la ley ${ }^{149}$.

después de varios años de negociación y estudios, en noviembre de 1416, Fernando I había aprobado una nueva formulación de este impuesto que suponía su ratificación: se cobraría tres dineros por libra de mercancía que pasase la frontera en ambas direcciones; la hacienda regia ingresaría una cuarta parte de la recaudación líquida. DIAGO HERNANDO, M. «La quema», p. 151-152

Al año siguiente, en las Cortes de Valladolid, petición tercera, se plantea de nuevo esta cuestión; la desalentadora respuesta es que ordenará escribir al rey de Aragón, tal como había contestado. Cortes, III, f. 33. B.N.E. MSS/1220, f. 14v-15r; 10628, f. 253v-254r; 10649, f. 146v; 11128, f. 6v-7r; 13104, f. 65r-65v; 11533, f. 466v-467r, y 13259, f. 27r-27v.

De nuevo se insiste en las Cortes de Ocaña de 1422, petición décimo novena, en la necesidad de adoptar medidas de presión, como hiciera Enrique III, que hicieran deseable al reino de Valencia la supresión de la quema. Se proponía, en concreto, el incremento de impuestos sobre la salida de ganado de Castilla hacia aquél reino: si no retiraban el impuesto, al menos se repararía el agravio a los castellanos. La respuesta sigue siendo muy suave: escribir al rey y a la reina de Aragón para que lo retiren. Cortes, III, f. 47-48. B.N.E. MSS/1220, f. 31v-33r; 10628, f. 279v-281r; 10649, f. 184r-185v; 11128, f. 40r-42r; 11533, f. 479r-479v; 13104, f. 93v-94v, y 13259, f. 33v-34r.

El impuesto sigue cobrándose en 1425, por lo que las Cortes de Palenzuela de este año, petición novena se quejan de esa circunstancia y piden soluciones; la respuesta, que proveerá sobre ello con la mayor rapidez posible, no auguraba resultado alguno. Cortes, III, f. 55-56. B.N.E. MSS/23, f. 195r; 1220, 41v-42r; 10628, f. 308r-309r; 10649, f. 219v-220v; 11128, f. 56v-57v; 11533, f. 497r-497v; 13104, f. 142v-143r, y 13259, f. 40r.

A raíz de esta petición se iniciaron negociaciones con Aragón, que no llegaron a solución alguna; el impuesto seguirá cobrándose y también se reproducirán las quejas de las Cortes castellanas en las sesiones de Madrid de 1435, petición décimo séptima, en las de Madrigal de 1438, petición cuarta, y en las de Valladolid de 1442, petición 34, en la que se menciona, además, otro nuevo impuesto cobrado desde 1430, denominado «dinero fajardo». En 1443 sigue cobrándose, como acredita una carta de la reina María de Aragón a su hermano el rey de Castilla, justificando la existencia del impuesto en virtud de ciertos acuerdos entre ambos reinos. DIAGO HERNANDO, M. «La quema», p. 155.

147 Petición cuarta. Cortes, III, f. 119-120. B.N.E. MSS/23, f. 211r; 1220, f. 119r-119v; 10649, f. 388v-389r; 11128, f. 190v-191v; 13105, f. 70r-70v. y f. 117r-117v, y 13259, f. 76v.

148 Petición sexta. La respuesta aplaza cualquier decisión durante ese tiempo y es, además, absolutamente difusa. Cortes, III, f. 121. B.N.E. MSS/23, f. 211v; 1220, f. 120v-121v; 10649, f. 390v-391v 11128, f. 193r-194r; 13105, f. 71v-72r, y 13259, f. 77r.

149 Es el caso de personas que se han casado durante ese tiempo o han superado el limite fiscal exento. Petición trigésimo sexta. Cortes, III, f. 145-146. B.N.E. MSS/1220, f. 144v-145r; 10649, f. 425r-426r; 11128, f. 232r-232v; 13105, f. 92r, y 13259, f. 87r. 
Especialmente plantea problemas la malévola actuación de algunos arrendadores de rentas y propios de las ciudades, que retienen las cantidades que han recaudado y, cuando se emiten sentencias contra ellos, las apelan e incluso obtienen cartas de comisión sobre el asunto, que se alarga para su beneficio particular y daño común. Por ello piden que los litigios sobre esas cantidades se libren ante regidores y alcaldes, sin apelación ni súplica, que no se otorguen nuevas comisiones sobre estas cuestiones y se revoquen las otorgadas, y reclaman una solución más rápida que la judicial, respuesta inicial del rey, siempre lenta para personas individuales, más aún para entes colectivos en los que siempre habrá alguna persona que apoye los deseos de los arrendadores de prolongar el asunto. La propuesta es que los arrendadores estén obligados a pagar las cantidades recaudadas en la misma forma establecida para las rentas reales, a lo que accede el rey, estableciendo también para las apelaciones el procedimiento seguido en aquéllas ${ }^{150}$.

Asunto importante en la fijación de las cargas fiscales es el establecimiento de repartimientos y derramas que, según parece, escapa a veces al control de los regidores. La práctica denunciada consiste en la aprobación de este tipo de aportaciones por los pecheros, bajo presión de los más importantes, con objeto de hacer dádivas que les permitan obtener favores en beneficio de una minoría, a costa del esfuerzo general. Por eso se pide que no se haga repartimiento alguno sin presencia de los regidores y justicias de la ciudad; accede el rey suprimiendo la obligación de pagar en repartimientos hechos en esta forma y promete disponer sobre las reclamaciones que se presenten contra tales acuerdos de ciudades que tengan privilegio para acordarlos ${ }^{151}$.

El justo reparto de las cargas fiscales exige un conocimiento exacto de los que están sujetos a dichas obligaciones y la supresión de toda posible evasión de las mismas; para ello es preciso disponer de censos actualizados y una estricta limitación de las exenciones fiscales a lo previsto en la ley.

En lo referente al censo, se hace imprescindible introducir las oportunas correcciones que recojan las fluctuaciones de población que se han producido, con el consiguiente desajuste en la carga contributiva. Ya se había planteado anteriormente este problema ${ }^{152}$, pero no se había aplicado solución alguna, lo que incrementa la despoblación de algunos lugares; se pide la adopción de medidas antes

150 Petición décimo tercera. Cortes, III, f. 129-130. B.N.E. MSS/23, f. 214r-214v; 1019, f. 29v y 32r-32v; 1220, f. 129r-130v; 6720, f. 45r-45v; 10649, f. 402r-405r; 11128, f. 206r-209r; 13105, f. 78v-79v, y 13259, f. 80r-81r.

151 Petición trigésimo tercera. Cortes, III, f. 143-144. B.N.E. MSS/23, f. 219; 1019, f. 34v-35r; 1220, f. 142v-143r; 6720, f. 49r-49v; 10649, f. 422r-423r; 11128, f. 227v-228v; 13105, f. 90r-90v, y 13259, f. 86r.

152 Había sido tratado, efectivamente, en las Cortes de Palencia de 1431, petición décimo tercera, Cortes, III, f. 102. B.N.E. MSS/1220, f. 97v-98r; 10649, f. 338v-339r; 11128, f. 153v-154r; 13105, f. 45r-45v, y 13259, f. 68r, y en las de Burgos de 1430, petición vigésimo sexta. Cortes, III, f. 90-91. B.N.E. MSS/1220, f. 83v-84v; 10649, f. 316r-317r; 11128, f. 128v-129v; 11533, f. 519r-519v; 13105, f. 15r-15v, y 13259, f. 58v-59r. En ambas ocasiones se había respondido que se proveería sobre el asunto, y, ante la insistencia de los procuradores de Burgos, se da orden a los contadores para que lo estudien. Como se ve, sin resultado alguno. 
del próximo repartimiento, aunque se tomen a partir de una somera información proporcionada por tesoreros y recaudadores, de modo que, si no resuelven totalmente el problema, suavicen al menos sus efectos negativos ${ }^{153}$.

Uno de los factores que ha incrementado los movimientos de población ha sido la emigración hacia los reinos vecinos y el trasvase de pecheros de lugares de realengo a señorío buscando una presión fiscal menor, aunque hayan tenido que aceptar condiciones y penalizaciones que les impiden volver a realengo en un momento determinado. Tratando de recuperar contribuyentes que alivien la presión sobre los que han permanecido en realengo, se pide que se declaren nulas aquellas condiciones, lo que permitirá el retorno y detendrá la corriente migratoria, que de otro modo se acrecentará ${ }^{154}$.

Para que la carga fiscal sea lo más justa posible, además de la actualización del censo, es preciso el establecimiento de niveles contributivos más justos, es decir una revisión de las cabezas de pecho, cuya inadecuada fijación en muchos lugares ha sido uno de las causas de los movimientos migratorios; al estar situada la cabeza de pecho más elevada en 1.200 maravedís, han de contribuir al mismo nivel quienes apenas superan esa tasación como los que la multiplican por cuarenta o cincuenta. Por eso se hace precisa una adecuada tasación de la mayor y, respecto a ella, de la mediana y la menor ${ }^{155}$.

La limitación de las exenciones fiscales hace preciso determinar quiénes tienen derecho a exención y delimitar a qué tributos se extiende la misma. Respecto a la determinación de los exentos, se pide que no gocen de los privilegios de la caballería quienes no cumplen las condiciones a que obliga tal estatuto, hecho que, dado el crecido número de pecheros que han recibido la caballería desde el comienzo del reinado, está provocando pleitos y escándalos. La petición recibe la aprobación real, con delimitación de las condiciones para disfrutar los privilegios de los caballeros ${ }^{156}$.

153 En esta ocasión se confía el estudio de este asunto a una comisión integrada por los contadores mayores bajo presidencia de Pedro Manrique, que actúa como hombre fuerte de la situación. Petición vigésimo primera. Cortes, III, f. 136-137. B.N.E. MSS/23, f. 216v-217r; 1220, f. 136r-136v; 10649, f. 412v-413v; 11128, f. 217r-218v; 13105, f. 84r-84v, y 13259, f. 83r-83v.

154 La respuesta es positiva, pero no podemos decir nada respecto a su efectividad. Petición cuadragésima. Cortes, III, f. 148-149. B.N.E. MSS/1019, f. 37r; 1220, f. 147v-148r; 6720, f. 50v-51r; 10649, f. 429v-430r; 11128, f. 237r-237v; 13105, f. 94v-95r, y 13259, f. 88r-88v.

155 La respuesta es una orden a los contadores para que informen de este asunto para adoptar las oportunas decisiones. Petición cuadragésimo octava. Cortes, III, f. 153-154. B.N.E. MSS/1220, f. 152v-153r; 10649, f. 437r-437v; 11128, f. 245v-246r; 13105, f. 98v-99r, y 13259, f. 91r.

156 Las condiciones del estatuto de caballeros, según los procuradores, son mantener continuamente caballo y armas y la obligación de servir en la guerra como si tuviesen tierra del rey. La respuesta regia precisa que los mayores de setenta años (el ms. de la B.N.E. 6370 indica sesenta años) no estarán obligados a ir personalmente a la guerra, aunque deberán enviar a alguien en su nombre; que cada caballero deberá mantener durante todo el año un caballo de un valor de 3.000 maravedís, arnés completo y una mula o jaca. Los hijos habidos antes de recibir la caballería no gozarán de exención; los habidos con posterioridad tendrán derecho a ella cumpliendo las mismas condiciones. Petición trigésimo cuarta. Cortes, III, f. 144-145. B.N.E. MSS/23, f. 219v; 1019, f. 35r-35v; 1220, f. 143r-144r; 6370, 
Por otra parte, la concesión de exenciones provoca muchos abusos y fraudes: las personas o instituciones que las reciben designan como excusados a los pecheros más ricos, aún en el caso de tratarse del desempeño de oficios menores, y siguen nombrando excusados incluso en lugares actualmente desiertos. Para evitarlo se pide que no se otorguen nuevas exenciones, que se amorticen las vacantes, que no todos los exentos sean los contribuyentes más altos y que quienes ya no tengan algunos de los oficiales declarados exentos no nombren a personas ajenas, obteniendo así un beneficio fraudulento ${ }^{157}$.

En cuanto a los tributos a que se extiende la exención y el carácter hereditario de la misma, así como los medios empleados por los eclesiásticos para defensa de sus privilegios, se plantean varias peticiones de Cortes. La pretensión de algunos oficiales regios de no contribuir en las derramas acordadas por las ciudades para atender a sus necesidades, alegando poseer privilegios que les hacen francos de todo pecho y derecho, motiva la petición, aceptada, de que sean obligados a hacerlo ${ }^{158}$. Respecto al carácter hereditario de la exención para las esposas e hijos de oficiales fallecidos, aunque se haya designado a otra persona para el desempeño del cargo, se señala que esa situación puede llevar a una desproporcionada generalización de la exención y se reclaman precisiones sobre ello y sobre los impuestos a que se refiere la exención ${ }^{159}$.

Por último se señala la pretensión de prelados, iglesias y monasterios de que sus exentos lo sean de todo pecho y tributo, y no solamente de monedas, como ya había sido establecido desde época de Juan I, argumentando que tal concesión, otorgada desde antiguo, no podía ser revocada ${ }^{160}$, y la abusiva forma en que utili-

f. 84 r; 10649, f. 423r-424r; 11128, f. 228v-230r; 13105, f. 91r-91v, y 13259, f. 86r-86v. El asunto de los exentos había sido objeto de atención de las Cortes de Palencia de 1431, petición décimo novena; en su respuesta, Juan II había confirmado una disposición suya de 20 de diciembre de 1422 por la que declaraba sujetos a todos los pechos reales y concejiles a todos los caballeros que anteriormente fueran pecheros. Vid. supra. Ahora se matizaban aquellas obligaciones.

157 También precisa el rey en su respuesta que no puedan ser designados exentos sino quienes sirvan personalmente el oficio y que no sean de los pecheros enteros; respecto a las vacantes que se produzcan se muestra absolutamente impreciso. Petición trigésimo novena. Cortes, III, f. 147-148. B.N.E. MSS/1019, f. 36v-37r; 1220, f. 146v-147r; 6720, f. 50r-50v; 10649, f. 428r-429v; 11128, f. 235r-237r; 13105, f. $93 v-94 v$, y 13259 , f. $87 v-88$ r.

158 Petición cuadragésimo cuarta. Los procuradores piden que estos oficiales contribuyan en estas derramas como lo hacen caballeros, escuderos, dueñas y doncellas hijosdalgo. Así se otorga. Cortes, III, f. 151. B.N.E. MSS/1019, f. 37v-38r; 1220, f. 149v-150r; 6720, f. 52r; 10649, f. 433r-433v; 11128, f. $241 \mathrm{r}-241 \mathrm{v} ; 13105$, f. $96 \mathrm{v}$, y 13259 , f. $89 \mathrm{v}$.

${ }^{159}$ La pretensión se apoya en una ordenanza de Enrique III, confirmada por Juan II, que había dispuesto que todos los oficiales, y sus mujeres e hijos, fueran libres de todo pecho y de monedas. Se pide que se precise si solo están exentos de moneda, como había establecido una ordenanza de Juan I, o realmente de todo pecho, y si este privilegio es realmente hereditario. La respuesta otorga la exención vitalicia a los oficiales, sin precisar a qué impuestos se refiere, y, tras su muerte, a sus viudas, si mantienen ese estado, pero obliga al pago a sus hijos. Petición trigésimo octava. Cortes, III, f. 146147. B.N.E. MSS/1019, f. 36r; 1220, f. 145v-146r; 6720, f. 49v-50r; 10649, f. 427r-428r; 11128, f. 234r-235r; 13105, f. 93r-93v, y 13259, f. 87v.

160 Denuncian los procuradores que, para defender su posición, los prelados y jueces eclesiásticos utilizan las censuras eclesiásticas contra los oficiales que pretenden cumplir sus funciones fiscales. Naturalmente el monarca ordena que se guarden las leyes sobre ello, es decir, que la exención se 
zan penas espirituales contra los arrendadores, cogedores y justicias, cuando pretenden cobrar legítimamente dichos impuestos o actuar contra quienes se niegan al pago y las maniobras para burlar el pago ${ }^{161}$.

Todas las peticiones se orientan a limitar todo lo posible el número de personas exentas de tributación y el de pechos a que hagan referencia las exenciones. Sin embargo, una petición va en sentido contrario, demostración de la influencia de las oligarquías urbanas en la vida de la ciudad y sobre la voz de los procuradores: es la que solicita la anulación de la reciente ordenanza que había establecido que los compradores de bienes de pecheros deberán pagar impuestos por ellos, independientemente de su situación y privilegios; exceptúan de dicha anulación a las compras realizadas por iglesias y monasterios, porque en ellas se produce una verdadera amortización ${ }^{162}$. Se pliega el rey a la petición y declara suspendida aquella ordenanza.

\section{Privilegios de las ciudades.}

Tratan los procuradores de obtener, una vez más, ciertos privilegios relativos a su contribución en la guerra, el respeto de las normas que rigen su gobierno y de su estatuto de realengo, y de recuperar alguna saneada renta, arrebatada recientemente. El hecho dominante en este capítulo, como también en el de petición de reparaciones e indemnizaciones, es la reiteración en la petición y el nulo resultado obtenido hasta el presente.

En lo relativo a la contribución al esfuerzo bélico, las ciudades solicitan de nuevo verse libres de las levas de pan, vino y pertrechos; la petición, presentada con anterioridad ${ }^{163}$, había obtenido la promesa de nombramiento de una comisión, presidida por Pedro Manrique, cuyos resultados eran desconocidos, que

refiere únicamente a monedas. Petición trigésimo séptima. Cortes, III, f. 146. B.N.E. MSS/1019, f. 35v; 1220, f. 145r-145v; 6720, f. 49r; 10649, f. 426r-427r; 11128, f. 233r-234r; 13105, f. 90v, y 13259, f. 87r-87v.

161 La trigésima petición ya había denunciado, además de la anterior, la utilización de excomunión y entredicho contra arrendadores, cogedores y justicias y el cobro en concepto de absolución de cantidades idénticas a las que deberían pagar en impuestos, en clara desobediencia a los límites establecidos por la normativa regia. Ordena el cumplimiento de la ley y que se le comuniquen los abusos que se produzcan para actuar en consecuencia. Cortes, III, f. 141-142. B.N.E. MSS/23, f. 218v 1220, f. 140r-141r; 6720, f. 48r-48v; 10649, f. 419r-420r; 11128, f. 224r-225v; 13105, f. 87v-88v, y 13259, f. $85 \mathrm{r}-85 \mathrm{v}$.

162 La ordenanza, como hemos visto, se halla incluida en la respuesta a la petición décimo novena de las Cortes de Palencia de 1431, y fue objeto de una ordenanza en diciembre de ese mismo año. El argumento ahora empleado es que su aplicación restaría compradores a los bienes de los pecheros o les perjudicaría en los precios, y que la compra de bienes pecheros por hidalgos no los amortiza, pues éstos también son, a su vez, vendedores. Petición trigésimo primera. Cortes, III, f. 142. B.N.E. MSS/23, f. 218v-219r; 1019, f. 34r-34v; 1220, 141r-142r; 6720, f. 48v-49r; 10649, f. 420v-421r; 11128, f. 225v-226v; 13105 , f. $88 \mathrm{v}$, y 13259 , f. $85 \mathrm{v}$.

163 Las destrucciones y el esfuerzo bélico provocado por la guerra con Aragón habían llevado a los procuradores, como hemos visto, a presentar esta solicitud en las Cortes de Burgos de 1430, petición cuarta, y en las de Palencia de 1431, asimismo petición cuarta, sin resultado alguno. 
ahora nuevamente se prometía ${ }^{164}$. Con objeto de salvaguardar lo más posible el funcionamiento de la administración urbana también se había pedido con anterioridad $^{165}$, y se pedía de nuevo, que no fuesen incluidos en los llamamientos los oficiales concejiles y quienes desempeñan oficios esenciales en el discurrir diario de la vida urbana, como físicos, cirujanos, maestros de gramática y escribanos $^{166}$, e igualmente aquellos que garantizan el funcionamiento de la maquinaria fiscal ${ }^{167}$. También se pide que las tropas urbanas no estén bajo el mando de señor alguno, salvo los propios capitanes o el rey, y ciertas normas de respeto a los pendones de la ciudad, cuya preeminencia habrá de ser respetada como en el pasado ${ }^{168}$.

También vuelven a plantear las ciudades anteriores peticiones sobre la libre designación de sus procuradores, y sobre las condiciones para ser elegible ${ }^{169}$, el respeto a la forma tradicional de elección de regidores y escribanos por los mismos que se hallan en ejercicio ${ }^{170}$, y la conservación de sus privilegios, jurados por el monarca en su toma de posesión del gobierno, que desde hacía poco tiempo estaban siendo quebrantados ${ }^{171}$. Preocupa especialmente a las ciudades la con-

${ }^{164}$ Se presentan en esta ocasión algunos abusos concretos y se demanda la puesta en marcha de la prometida comisión, respecto a la que nada se sabe. Petición décimo octava. Cortes, III, f. 134-135. B.N.E. MSS/23, f. 216r; 1220, f. 134r-134v; 10649, f. 409v-411r; 11128, f. 214v-215v, 13105, f. 82-83r, y 13259, f. 82v.

165 Cortes de Burgos de 1430, petición 32. En aquella ocasión lo otorgó el monarca, pero solamente por ese año.

166 Ahora se plantea de nuevo la petición a la que el monarca accede, salvo si se hallase en gran necesidad; las perspectivas de paz hacían más fácil acceder ahora al deseo de los procuradores. Petición vigésimo tercera. Cortes, III, f. 137-138. B.N.E. MSS/23, f. 217r; 1220, f. 137r-137v; 6720, f. $47 r-47 v$; 10649, f. 414r-414v; 11128, f. 219r-219v; 13105, f. 85r, y 13259, f. 83v-84r.

167 Se había pedido en las Cortes de Burgos de 1430, petición trigésimo tercera, que esta exención, sobre la que se había redactado una ordenanza referida a arrendadores y recaudadores se extendiera a empadronadores, cogedores y pesquisidores. Ahora se reclama su efectiva aplicación. Petición vigésimo cuarta. Cortes, III, f. 138. B.N.E. MSS/23, f. 217r-217v; 1220, f. 137v-138r; 6720, f. 47v; 10649, f. 414v-415r; 11128, f. 219v-220r; 13105, f. 85r-85v, y 13259, f. 84r.

168 Los pendones de las ciudades no esperarán a nadie, salvo al rey y al príncipe heredero; no obstante, cuando hayan partido los pendones, la gente esperará a quien el rey ordene. Petición cuadragésimo tercera. Cortes, III, f. 150-151. B.N.E. MSS/1220, f. 149r-149v; 6720, f. 51v; 10649 , f. 432r-433r; 11128, f. 240r-240v; 13105, f. 96r-96v, y 13259, f. 89r-89v.

169 Se pide que sean dos los procuradores, nombrados libremente por la ciudad, que no sean labradores ni sesmeros; ahora las ciudades insisten en esas condiciones y piden que se restrinja por ley el acceso al cargo de procurador, excluyendo a ciudadanos de baja condición. La respuesta regia se limita a encomendar la elección a la libre voluntad de las ciudades y que las diferencias se sustancien ante los tribunales. Petición décimo novena. Cortes, III, f. 135. B.N.E. MSS/23, f. 216r-216v; 1220, f. 134v-135v; 10649, f. 411r-412r; 11128, f. 215v-216v; 13105, f. 83r-83v, y 13259, f. 82v-83r. Ya había sido planteada esta cuestión en las Cortes de Burgos de 1430, petición 13, y en las de Palencia de 1431, petición 9; en ambas el rey se había ceñido en su respuesta a respetar la libertad de elección de las ciudades.

170 Petición vigésimo segunda. Cortes, III, f. 137. B.N.E. MSS/23, f. 217r; 1220, f. 136v-137r; 6720, f. $47 r ; 1019$, f. 33r-33v; 10649, f. 413v-414r; 11128, f. 218v-219r; 13105, f. 84v-85r, y 13259, f. 83v-84r El sistema de designación de regidores para cubrir las vacantes producidas había sido planteado en las Cortes de Burgos de 1430 en dos peticiones: en la vigésimo novena se pide respeto al sistema tradicional; en la trigésimo séptima se añade que esta costumbre ha sido trasgredida recientemente.

171 Se trata de una reclamación general de respeto a los privilegios jurados; la respuesta real pide que se concreten los casos en que tales privilegios no han sido respetados. Petición trigésimo segunda. Cortes, III, f. 142-143. B.N.E. MSS/23, f. 219; 1220, f. 142r-142v; 10649, f. 421r-422r; 11128, f. 226v-227v 13105 , f. 89 r, y 13259 , f. $85 v-86$ r. 
servación de su condición de realengo, sobre todo teniendo en cuenta la tendencia a recompensar servicios mediante la concesión de algunas ciudades que así pasaban de realengo a señorío ${ }^{172}$.

Completa este capítulo relativo a sus privilegios la pretensión de recuperar la renta de los tableros de juego que proporcionaba a las ciudades saneados ingresos con los que atender a sus necesidades comunales. La prohibición, que había terminado con los ingresos, no lo había hecho con el juego; el hecho es todavía más afrentoso porque la prohibición de arrendamiento no había alcanzado a personas que tenían tal renta por merced. Por ello piden la restitución del derecho y una indemnización por las cantidades no ingresadas: el deseo de mantener la prohibición del juego hace que el monarca solo les otorgue las penas por infracción de esta norma ${ }^{173}$.

\section{Abusos y corrupción.}

Los abusos señalados en esta ocasión por las ciudades se refieren al aposentamiento en ellas de los poderosos y toma de sus bienes y términos, las maniobras para el cobro de peajes abusivos, la saca de cosas vedadas, los engaños en la concentración de tropas y en los alardes y la escandalosa protección de que gozan muchos delincuentes en sus ciudades, lo que impide su captura y procesamiento.

El aposentamiento de caballeros y prelados en las casas de los vecinos es ocasión de tomas de bienes y de muchos actos deshonrosos; sobre estos hechos, ya denunciados, se habían tomado disposiciones ${ }^{174}$, que, afirman, no se han cum-

172 Petición vigésima. Cortes, III, f. 136. B.N.E. MSS/23, f. 216v; 1220, f. 135v; 10649, f. 412r-412v; 11128 , f. 216v-217r; 13105 , f. $83 v-84$ r, y 13259, f. 83 r.

${ }_{173}$ Petición vigésimo novena. Cortes, III, f. 140-141. B.N.E. MSS/23, f. 218r-218v; 1019, f. 33v-34r; 1220, f. 139v-140r; 6720, f. 47v-48r; 10649, f. 418r-419r; 11128, f. 223r-224r; 13105, f. 87r-87v, y 13259, f. 85r.

174 Esta cuestión había sido objeto de la preocupación de las Cortes desde las primeras del reinado propiamente dicho, las de Madrid de 1419, petición décimo sexta. Insistieron entonces en las vejaciones de que era víctimas las mujeres, reclamaron que se pagasen las posadas, señalaron lugares inapropiados para dar posada, como paneras, bodegas y mesones, y pidieron que dos aposentadores de la ciudad acompañen a los del rey cuando se fijen los aposentamientos. Cortes, III, f. 19-20. B.N.E. MSS/1220, f. 9r-9v; 6720, f. 16r; 17r; 10628, f. 228v-230r; 10649, f. 132r-133v; 11127, f. 226r-228r; 11533, f. 488r-489r; 13104, f. 26r-27r, y 13259, f. 21r. Al año siguiente, las Cortes de Valladolid, petición segunda, señalaron que las mencionadas órdenes no solo no se habían cumplido sino que el rey había dado órdenes en contrario mediante apremiantes cartas; piden que se cumpla lo dispuesto en las anteriores, a lo que accede el rey. Cortes, III, f. 32-33. B.N.E. MSS/1220, f. 13v-14v; 6720, f. 18r-18v; 10628, f. 252r-253v; 10649, f. 145r-146v; 11128, f. 4v-6r; 13104, f. 64r-65r; 11533, f. 466r-466v, y 13259, f. 27r.

De nuevo vuelven sobre el asunto las Cortes de Palenzuela de 1425, petición cuarta. Afirman los procuradores que nada se ha hecho al respecto, pese a haberlo solicitado hasta en tres ocasiones. Se disculpa el rey, por las muchas obligaciones, y promete resolverlo en breve. Cortes, III, f. 53-54. B.N.E. MSS/23, f. 194r-194v; 1220, f. 38v-39v; 10628, f. 304v-305r; 10649, f. 215v-216v; 11128, f. 52r-53r; 11533, f. $495 \mathrm{r}-495 \mathrm{v} ; 13104$, f. 140v-141r, y 13259, f. 39r-39v. 
plido, por lo que piden nuevas órdenes de cumplimiento previendo severas penas para sus responsables y los justicias y regidores que lo consientan ${ }^{175}$.

La toma de bienes urbanos por prelados y caballeros es un problema que se ve agravado por las dificultades de hacer frente a esa situación, tanto por la fuerza, dada la potencia de los usurpadores y los apoyos con que cuentan dentro de las propias ciudades, como por vía jurídica, en la que los poderosos cuentan con sus elevados recursos y la capacidad de maniobra. Por eso habían pedido solución para estos hechos; sin embargo, la respuesta real, que lo demanden en derecho, resultaba inoperante ${ }^{176}$. Por eso piden ahora que se resuelva por vía de expediente, habida información de personas adecuadas, y se ejecute la justicia pospuesta toda apelación, súplica o petición de nulidad ${ }^{177}$.

Resultan especialmente perjudiciales para los intereses de las ciudades los excesos que se perpetraban en los lugares de cobro de peajes: exigencia de portazgos y otros gravámenes sobre mercancías no sujetas a esos tributos, y tomas de bienes que no podían ser embargados en pago; sobre todo, la picaresca en la recaudación: no poner recaudadores en los lugares correspondientes, para luego tomar por descaminados a los que no han podido satisfacer el peaje y tomarles sus bienes o someterles a cohecho. Se había pedido, y así lo había otorgado el rey en su respuesta, que no se cobraran portazgos de las cosas no sujetas a pago, que los recaudadores estuvieran en los lugares acostumbrados y, si no lo estaban, que las mercancías pasasen sin incurrir en pena alguna ${ }^{178}$. La petición se reitera ahora, solicitando que la orden tenga rango de ley, porque las disposiciones anteriores no se habían cumplido, a lo que accede el rey ${ }^{179}$.

En ese mismo sentido, se quejan las ciudades de las sacas ilegales de mercancías vedadas, delito que se hace posible por la connivencia entre los alcaldes de sacas y sus lugartenientes con autoridades de los lugares fronterizos del reino; una queja similar, relacionada con la salida de moneda del reino, que provocaba escasez de numerario con las consiguientes secuelas económicas, se había pre-

175 Ordena el rey que así se cumpla. Establece una sanción de 600 maravedís y el triple del valor de lo tomado, que será descontado de las cantidades que hubiere de percibir del rey; si no tuviere con qué pagar se tomará de sus bienes; los jueces y justicias que no ejecuten las penas o den posadas sin mandato serán privados de sus oficios. Petición novena. Cortes, III, f. 123-124. B.N.E. MSS/23, f. 212r-212v; 1019, f. 27v-28r; 1220, f. 123r-124r; 6720, f. 42r-42v; 10649, f. 394r-395v; 11128, f. 197r-198v; 13105, f. 73v-74v, y 13259, f. 78r.

176 Cortes de Palenzuela de 1425, petición trigésimo segunda. Cortes, III, f. 71-72. B.N.E. MSS/23, f. $201 v$; 1220, f. 59v-60v; 10628, f. 333v-335r; 10649, f. 244r-246r; 11128, f. 88r-89v; 13104, f. 158v-160v, y 13259 , f. $46 v-47 r$.

177 Petición duodécima. Cortes, III, f. 128-129. B.N.E. MSS/23, f. 213v-214r; 1220, f. 128r-129r; 10649, f. 401r-402r; 11128, f. 204v-206r; 13105, f. 77v-78v, y 13259, f. 80r.

178 Petición trigésimo octava de las Cortes de Palenzuela de 1425, que habían tenido un carácter de organización institucional con muchas similitudes con éstas de Zamora de 1432. Cortes, III, f. 75-76. B.N.E. MSS/23, f. 203r-203v; 1019, f. 15v-16r; 1220, f. 64r-65v; 6720, f. 28v-29r; 10628, f. 339v-341r; 10649, f. 251r-252v; 11128, f. 95v-97v; 13104, f. 163r-164r, y 13259, f. 48r-48v.

179 Petición décimo quinta. Cortes, III, f. 131-132. B.N.E. MSS/23, f. 215r-215v; 1019, f. 32v-33r; 1220, f. 131r-132v; 6720, f. 46r-46v; 10649, f. 405v-407v; 11128, f. 210r-212r; 13105, f. 80r-81r, y 13259, f. 81r-81v. 
sentado en las Cortes de Palenzuela de $1425^{180}$. La respuesta a la nueva petición condena estas prácticas castigándolas con penas extraordinariamente severas ${ }^{181}$.

La guerra con Aragón y la reciente campaña de Granada habían puesto de relieve algunas prácticas fraudulentas en la reunión de tropas. Una de ellas, de carácter político fundamentalmente, es la reunión de un número de hombres de armas inferior al convocado, hecho encubierto con diferentes maniobras, con el consiguiente riesgo militar, fácilmente comprensible; por otra parte, un fraude económico, consistente en formar parte de varios alardes, lo que supone inflar artificialmente los costes de cualquier campaña.

El primero de los casos, una menor respuesta a la convocatoria militar, debió ser especialmente sensible en el caso del enfrentamiento con Aragón y Navarra, en el que los partidarios de los Infantes, lógicamente, hurtaron su apoyo al rey. Naturalmente se trataba de sancionar aquella conducta. Un hecho ya reclamado en las Cortes de Burgos de 1430 y en las del Palencia del año siguiente ${ }^{182}$, respecto al que se habían prometido medidas pero sobre el que, a juicio de las Cortes, nada se había hecho, incluso se cometía ahora un mayor número de irregularidades ${ }^{183}$.

La multiplicidad de alardes tiene un sentido más económico, de simple fraude; también había sido objeto de las peticiones de las Cortes de Burgos y Palencia ${ }^{184}$, pero nada parecía haberse hecho al respecto, y las gravísimas sanciones impuestas las hacían poco creíbles, de modo que se solicita una previsión de penas más realista y, para mayor efectividad de lo dispuesto, el pago del sueldo en dinero contante y no en libramiento ${ }^{185}$.

180 Portugal, Aragón y la Curia son los lugares señalados, lógicamente, como destino del dinero salido del reino. Petición vigésimo segunda. Cortes, III, f. 65-66. B.N.E. MSS/23, f. 199r; 1220, f. 53r-53v; 10628, f. 324v-325r; 10649, f. 235v-236r; 11128, f. 76r-76v; 11533, f. 504v; 13104, f. 152v-153r, y 13259, f. $44 \mathrm{r}$.

181 Se ordena realizar las oportunas pesquisas; las sanciones establecidas son pérdida de oficio, confiscación de bienes y pena de muerte. Petición cuadragésimo primera. Cortes, III, f. 149. B.N.E. MSS/1019, f. 37v; 1220, f. 148r-148v; 6720, f. 51r-51v; 10649, f. 430r-431r; 11128, f. 238r-238v; 13105, f. $95 \mathrm{r}$, y 13259 , f. $88 \mathrm{v}$.

182 Petición primera en ambas sesiones. Vid. supra. Las de Burgos se refieren a la guerra con Aragón; las de Palencia denuncian idéntica práctica en la campaña de Granada. La insuficiente respuesta en este segundo caso, en íntima conexión con las razones de la guerra anterior, se debió, seguramente, a que algunos interpretaron que un éxito de la oligarquía gobernante no convenía a sus intereses. Sin duda, es una de las razones de las graves divisiones que se han señalado en las fuerzas expedicionarias y que aconsejaron abreviar la campaña en la Vega de Granada.

${ }^{183}$ La respuesta regia prevé ahora una investigación en los libros sobre la gente que fue convocada en estos tres últimos años y quiénes se abstuvieron de responder a la convocatoria, y la aplicación de los oportunos castigos. Es indudable que se pone en marcha un instrumento de represión contra los no afectos al grupo gobernante. Petición décimo sexta. Cortes, III, f. 132-133. B.N.E. MSS/23, f. 215v; 1220, f. 132v-133r; 10649, f. 407v-408v; 11128, f. 212r-213v; 13105, f. 81v-82r, y 13259, f. 81v-82r.

184 Petición segunda en ambas sesiones. En las de Burgos, ante la insistencia de los procuradores, se castigan los alardes múltiples con diez años de servicio en las atarazanas, sin el responsable es hidalgo, y cien azotes, para hombres de menor importancia. Vid. supra.

${ }^{185}$ Las penas ahora establecidas son, para los hidalgos, un año de servicio en las atarazanas y pérdida de la tierra, si la tuviere del rey; para los de menor guisa, treinta azotes. Respecto al sueldo, 
Otra petición de estas Cortes muestra un aspecto importante de la situación de división interna al que el nuevo gobierno pretende poner fin, exponente de toda la labor de estas sesiones. Se refiere a la protección de que gozan en sus ciudades y villas numerosos delincuentes, responsables de los más graves crímenes, ante los que se muestran impotentes no solo las víctimas y las autoridades de los lugares en que se han cometido, sino también los justicias de Casa, Corte y Chancillería. Indudablemente, no se trata solo de delitos, en el sentido más directo del término, sino, sobre todo, de acciones de rapiña y violencias cometidas al amparo de los enfrentamientos internos; la inclusión entre estos delincuentes de aquellos prestatarios que, al amparo de ese privilegio, se niegan al pago de deudas, nos habla con claridad de que no se trata de simples delincuentes, sino de miembros de las banderías que dividen el reino ${ }^{186}$.

La Cortes habían aportado soluciones para superar los daños de la guerra y sentar las bases institucionales de un fuerte gobierno, señalado abusos y defectos y reclamado acciones de gobierno para resolverlos. Han realizado un gran esfuerzo en defensa de sus intereses políticos, institucionales, jurídicos, fiscales y económicos, han soportado una pesada carga fiscal y visto como los fondos reclamados con un determinado fin iba a financiar empresas diferentes. Han denunciado, en fin, el incumplimiento reiterado de los compromisos adquiridos en las respuestas a sus peticiones, recogidas en los Cuadernos de Cortes.

La viabilidad del gobierno de la oligarquía dependerá en gran medida de la adecuada respuesta a las peticiones y de la efectiva aplicación, o no, de las medidas propuestas. Desde luego, las Cortes, que seguirán quejándose reiteradamente de aquellos incumplimientos, tratan de sentar las bases de un gran proceso de renovación institucional y administrativa.

el rey se muestra dispuesto al pago en dinero, si los procuradores establecen medios para que pueda disponer de él. Petición décimo séptima. Cortes, III, f. 133-134. B.N.E. MSS/23, f. 215v-216r; 1220, f. $133 r-134$ r; 6720 , f. $46 v-47$ r; 10649 , f. $408 v-409 v ; 11128$, f. $213 v-214 v ; 13105$, f. $82 r-82$, y 13259 f. $82 \mathrm{r}-82 \mathrm{v}$.

${ }^{186}$ La respuesta real ordena que, no obstante cualquier privilegio, los responsables sean enviados a los lugares en que delinquieron, para ser sometidos a la acción de la justicia, hecho que, dada la realidad del reino, acaso no pasaba de ser un loable proyecto. Petición cuadragésimo quinta. Cortes, III, f. 151-152. B.N.E. MSS/1019, f. 38r-39r; 1220, f. 150r-151v; 6720, f. 52r-53r; 10649, f. 433v-435v; 11128 , f. $241 v-244 r ; 13105$, f. $96 v-98$ r, y 13259 , f. 89v-90v. 
